\title{
Performance and thermal stability of an a-Si:H/TiOx/Yb stack as an electron-selective contact in silicon heterojunction solar cells
}

Citation for published version (APA):

Cho, J., Melskens, J., Payo, M. R., Debucquoy, M., Radhakrishnan, H. S., Gordon, I., Szlufcik, J., Kessels, W. M. M., \& Poortmans, J. (2019). Performance and thermal stability of an a-Si:H/TiOx/Yb stack as an electronselective contact in silicon heterojunction solar cells. ACS Applied Energy Materials, 2(2), 1393-1404. https://doi.org/10.1021/acsaem.8b01969

\section{Document license:}

TAVERNE

DOI:

10.1021/acsaem.8b01969

Document status and date:

Published: 25/02/2019

\section{Document Version:}

Publisher's PDF, also known as Version of Record (includes final page, issue and volume numbers)

\section{Please check the document version of this publication:}

- A submitted manuscript is the version of the article upon submission and before peer-review. There can be important differences between the submitted version and the official published version of record. People interested in the research are advised to contact the author for the final version of the publication, or visit the DOI to the publisher's website.

- The final author version and the galley proof are versions of the publication after peer review.

- The final published version features the final layout of the paper including the volume, issue and page numbers.

Link to publication

\footnotetext{
General rights

- You may freely distribute the URL identifying the publication in the public portal. follow below link for the End User Agreement:

www.tue.nl/taverne

\section{Take down policy}

If you believe that this document breaches copyright please contact us at:

openaccess@tue.nl

providing details and we will investigate your claim.
}

Copyright and moral rights for the publications made accessible in the public portal are retained by the authors and/or other copyright owners and it is a condition of accessing publications that users recognise and abide by the legal requirements associated with these rights.

- Users may download and print one copy of any publication from the public portal for the purpose of private study or research.

- You may not further distribute the material or use it for any profit-making activity or commercial gain

If the publication is distributed under the terms of Article 25fa of the Dutch Copyright Act, indicated by the "Taverne" license above, please 


\title{
Performance and Thermal Stability of an a-Si:H/TiO $/ \mathrm{Yb}$ Stack as an Electron-Selective Contact in Silicon Heterojunction Solar Cells
}

\author{
Jinyoun Cho,,,$+ \neq \odot$ Jimmy Melskens, ${ }^{\S}$ Maria Recaman Payo, ${ }^{*}$ Maarten Debucquoy, \\ Hariharsudan Sivaramakrishnan Radhakrishnan, ${ }^{\ddagger}$ Ivan Gordon, ${ }^{\ddagger}$ Jozef Szlufcik, ${ }^{\ddagger}$ W. M. M. Kessels, ${ }^{\S \odot}$ \\ and Jef Poortmans ${ }^{\dagger,+, \| l}$
}

${ }^{\dagger}$ ESAT Department, K. U. Leuven, Leuven 3001, Belgium

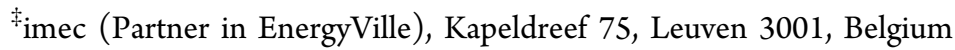

${ }^{\S}$ Department of Applied Physics, Eindhoven University of Technology, P. O. Box 513, 5600 MB Eindhoven, The Netherlands

"University Hasselt, Martelarenlaan 42, Hasselt 3500, Belgium

Supporting Information

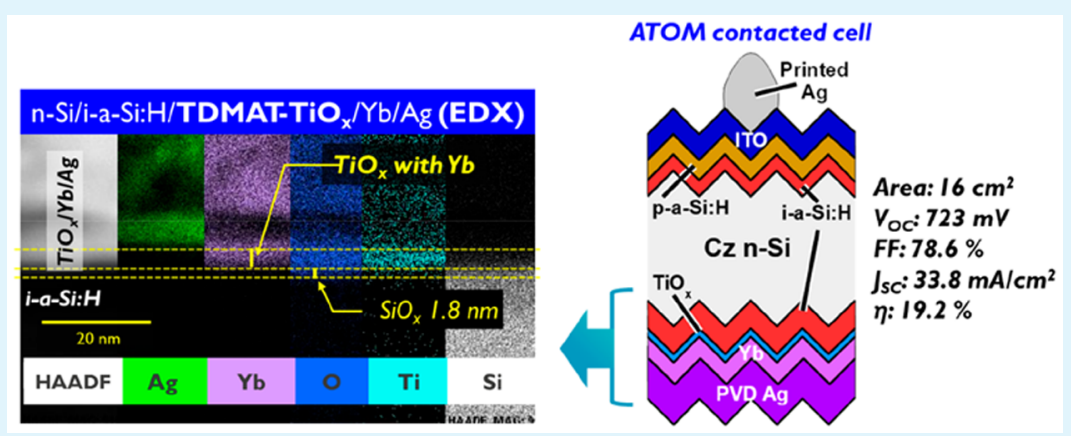

ABSTRACT: Low contact resistivity $\left(\rho_{\mathrm{c}}\right)$ and low recombination current density at the metallized area $\left(J_{0, \text { metal }}\right)$ are the key parameters for an electron-selective contact in solar cells, and an $\mathrm{i}-\underline{a}-\mathrm{Si}: \mathrm{H} / \underline{\mathrm{TiO}}_{x} /$ low work function $\underline{\text { metal }}$ (ATOM) structure could satisfy these criteria. In this work, to achieve strong downward band bending, an $\mathrm{Yb}(\Phi=2.5-2.6 \mathrm{eV}) / \mathrm{Ag} \mathrm{stack}$ is used. Moreover, the impact of (1) substrate topography (flat or textured), (2) $\mathrm{TiO}_{x}$ thickness, and (3) Ti precursor (TTIP vs TDMAT) on the ATOM contact performance is investigated. The results show that the ATOM contact is relatively insensitive to the surface topography and to the Ti precursors (TTIP or TDMAT) used for the atomic layer deposition (ALD) of TiO . However, the $\mathrm{TiO}_{x}$ thickness has a significant impact on the $\rho_{\mathrm{c}}$ and marginally on the $J_{0, \text { metal }}$ of the ATOM contact. For all topography cases and $\mathrm{Ti}$ precursors, $1 \mathrm{~nm}$ thick $\mathrm{TiO}_{x}$ results in the lowest $\rho_{\mathrm{c}}$ value, most likely due to $E_{\mathrm{F} \text {,metal }}$ depinning. In the silicon heterojunction solar cell, this ATOM contact (i-a-Si:H/TiO ${ }_{x} / \mathrm{Yb} / \mathrm{Ag}$ ) yields a solar cell efficiency of $19.2 \%$ with a high $V_{\mathrm{OC}}$ of $723 \mathrm{mV}$ without the need of a doped n-a-Si:H layer. Concerning the thermal stability of these contacts, TEM images confirm that $\mathrm{Yb}$ does not diffuse into the $\mathrm{i}$-a-Si:H layer after an annealing at $180{ }^{\circ} \mathrm{C}$ for 30 min thanks to the $\mathrm{TiO}_{x}$ layer behaving as a diffusion barrier. $98 \%$ of the initial solar cell efficiency is preserved even after successive annealing treatments at 150 and $175^{\circ} \mathrm{C}$, which are values in the same temperature range used in the module lamination and the sintering of the printed Ag. These results in combination with the demonstrated efficiency underline that the ATOM contact is a promising route to realize high-efficiency solar cells.

KEYWORDS: low work function metal, Yb, MIS contact, electron-selective contact, passivating contact

\section{INTRODUCTION}

Two-side-contacted silicon heterojunction $(\mathrm{SHJ})$ solar cells are very attractive because of the high-efficiency potential and the relatively simple process flow for fabrication. ${ }^{1}$ Intrinsic hydrogenated amorphous silicon (i-a-Si:H) layers in $\mathrm{SHJ}$ solar cells provide excellent chemical surface passivation, while n-type or p-type hydrogenated amorphous silicon (n-a-Si:H or $\mathrm{p}-\mathrm{a}-\mathrm{Si}: \mathrm{H}$ ) layers, added on top of the $\mathrm{i}-\mathrm{a}-\mathrm{Si}: \mathrm{H}$, induce band bending at the surface region of the c-Si substrate, which results in field-effect passivation. The band offsets between the c-Si and a-Si:H stacks give rise to the electron and hole selectivity at the a-Si:H $(\mathrm{i} / \mathrm{n})$ and $\mathrm{a}-\mathrm{Si}: \mathrm{H}(\mathrm{i} / \mathrm{p})$ contacts. In spite of the good chemical and field-effect passivation of the a$\mathrm{Si}: \mathrm{H}$ stack $(\mathrm{i} / \mathrm{n}$ or $\mathrm{i} / \mathrm{p})$, there are significant optoelectrical losses associated with a-Si:H, in particular when it is doped. ${ }^{2}$ For this reason, fine-tuning the deposition conditions and the layer thickness of doped a-Si:H is required to minimize those losses. In another approach, carrier-selective contacts can also

Received: November 12, 2018

Accepted: January 18, 2019

Published: January 18, 2019 
be realized without such doped layers, by using transition metal oxides (TMOs) instead. TMOs have been recently getting more attention because of their high band gap, typically above $3 \mathrm{eV}$, and their asymmetric band structure with respect to $\mathrm{c}-\mathrm{Si}^{3-5}$

Typically, contacts that do not include a doped layer have relatively high contact resistivity $\left(\rho_{\mathrm{c}}\right)$ and low contact passivation quality, ${ }^{6}$ characterized by a high recombination current density $\left(J_{0}\right)$, because of a weak or undesired band bending. By introducing metal oxide layers in solar cell contacts, advantageous band bending and contact passivation have been achieved. Depending on the work function and band offsets, TMOs can be used as either electron- or hole-selective contacts to replace heavily doped regions and doped a-Si:H layers. Regarding electron-selective contacts, several research groups have demonstrated low $\rho_{\mathrm{c}}$ and low $J_{0}$ using different metal oxides/nitrides in combination with different metals, such as $\mathrm{TiO}_{x} / \mathrm{Al}^{7-9} \mathrm{MgO}_{x} / \mathrm{Al}^{10}{ }^{10} \mathrm{NbO}_{x} / \mathrm{Al}^{11,12} \mathrm{TaO}_{x} / \mathrm{Mg} /$ $\mathrm{Ag},{ }^{13}$ and $\mathrm{TaN}_{x} / \mathrm{Al}^{14}$ Moreover, to further reduce $\rho_{\mathcal{c}}$, lower work function metals have been investigated either individually, e.g., $\mathrm{Ca} / \mathrm{Al},{ }^{15}$ or in combination with other materials such as alkaline earth metal fluorides, e.g., $\mathrm{LiF} / \mathrm{Al}^{4}$ and $\mathrm{MgF} / \mathrm{Al}$ 164,16 and/or metal oxides, e.g., $\mathrm{TiO}_{x} / \mathrm{LiF} / \mathrm{Al}^{3}$ and $\mathrm{TiO}_{x} / \mathrm{Ca} /$ Al. $^{6,17-19}$

On the other hand, as hole-selective contacts, TMOs with a high work function, i.e., $\mathrm{MoO}_{x}, \mathrm{WO}_{x}$, and $\mathrm{VO}_{x}$, have also been intensively studied by many groups to replace $\mathrm{p}-\mathrm{a}-\mathrm{Si}: \mathrm{H}$ in $\mathrm{SHJ}$ solar cells because these TMOs induce upward band bending at the hole contact region with reduced parasitic absorption. $^{20-26}$ When TMO-based hole- and electron-selective contacts are integrated into the same device, doping processes or doped layers can be completely eliminated. However, the deposition of TMO layers enforces a more constrained processing window where the temperature should be kept below approximately $180{ }^{\circ} \mathrm{C}$ to avoid severe performance degradation of TMOs. ${ }^{27,28}$

To satisfy these requirements, the ATOM (i-a- $-\mathrm{Si}: \mathrm{H} / \mathrm{TiO}_{x} /$ low work function metal) contact has been developed as a high-quality electron-selective contact structure without an ntype a-Si:H layer, ${ }^{6,17}$ having a metal-insulator-semiconductor (MIS) structure where $\mathrm{i}-\mathrm{a}-\mathrm{Si}: \mathrm{H}$ and $\mathrm{TiO}_{x}$ act as the semiconductor and the insulator, respectively. The $\mathrm{i}-\mathrm{a}-\mathrm{Si}: \mathrm{H}$ layer is the main contact passivation layer, but placing a metal directly in contact with $\mathrm{i}-\mathrm{a}-\mathrm{Si}: \mathrm{H}$ would result in the pinning of its Fermi level..$^{29,30}$ For a simple test structure resembling a

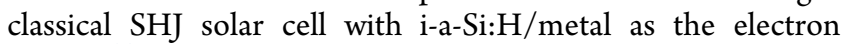
contact, $^{30}$ the pinning factor $(S)$ for this contact structure is estimated to be around $0.3,{ }^{30}$ which indicates that strong pinning occurrs on the a-Si: $\mathrm{H} /$ metal interface. To mitigate this problem in the ATOM contact, a thin $\mathrm{TiO}_{x}$ layer is used. Inserting the $\mathrm{TiO}_{x}$ layer between $\mathrm{i}-\mathrm{a}-\mathrm{Si}: \mathrm{H}$ and the metal reduces the $\rho_{\mathrm{c}}$ thanks to the metal Fermi level depinning effect. $^{6,17}$

Atomic layer deposition (ALD) has been demonstrated as a promising fabrication method to grow $\mathrm{TiO}_{x}$ such that the passivation quality provided by the underlying a-Si:H passivation layer is preserved. ${ }^{17,31}$ Using the $\mathrm{i}$-a- $\mathrm{Si}: \mathrm{H} / \mathrm{TiO}_{x} /$ $\mathrm{Ca}(\Phi=2.9 \mathrm{eV})$ stack with an $\mathrm{Al}$ capping layer, ${ }^{17}$ where $\mathrm{Ca}$ is the low work function metal of the ATOM contact, a low $\rho_{\mathrm{c}}$ of $15 \mathrm{~m} \Omega \cdot \mathrm{cm}^{2}$ and a low $J_{0 \text {,metal }}$ (recombination current density at the metallized areas) of about $13 \mathrm{fA} / \mathrm{cm}^{2}$ could be achieved, which represents an excellent electron-selective contact. In our previous work, this electron-selective ATOM contact was studied using titanium isopropoxide (Ti[OCH- $\left.\left(\mathrm{CH}_{3}\right)_{2}\right]_{4}$, TTIP) as the ALD Ti precursor and a fixed $\mathrm{TiO}_{x}$ thickness of $2 \mathrm{~nm}$ on a flat surface. ${ }^{17}$ However, a detailed parameter study of the ATOM contact was not performed in previous work. ${ }^{17}$

In this work, the influence of the substrate topography and the $\mathrm{TiO}_{x}$ thickness on the ATOM contact performance was studied in detail. Furthermore, a new $\mathrm{Ti}$ precursor (tetrakis(dimethylamido)titanium ( $\mathrm{Ti}\left[\mathrm{N}\left(\mathrm{CH}_{3}\right)_{2}\right]_{4}$, TDMAT, $0.43 \AA$ / cycle at $225^{\circ} \mathrm{C}$ ) was also investigated as an alternative ALD Ti precursor to TTIP because of its potential to overcome the lower growth rate per cycle $\left(0.18 \AA /\right.$ cycle at $\left.200{ }^{\circ} \mathrm{C}\right)$ when using TTIP. As a low work function metal, $\mathrm{Yb}(\Phi=2.5-2.6$ $\mathrm{eV})$ was applied instead of $\mathrm{Ca}(\Phi=2.9 \mathrm{eV})$ in the ATOM contact structure ${ }^{32,33}$ to enhance the downward band bending at the contact region because of its lower work function. Then, $\mathrm{SHJ}$ solar cells were fabricated using the optimized ATOM contact based on $\mathrm{i}-\mathrm{a}-\mathrm{Si}: \mathrm{H} / \mathrm{TiO}_{x} / \mathrm{Yb} / \mathrm{Ag}$. As a reference, $\mathrm{SHJ}$ solar cells with an i-a-Si:H/Yb/Ag (no $\mathrm{TiO}_{x}$ or $\mathrm{n}$-a-Si:H) contact and a classical i/n-a-Si:H/ITO/Ag contact were also fabricated. Finally, the thermal stability of the developed ATOM contact was also studied using annealing treatments at various temperatures.

\section{EXPERIMENTAL METHODS}

2.1. Sample Preparation. 2.1.1. Test Structures for $J_{0}, J_{0 \text { metal }}$ and $\rho_{c}$ Evaluation. Double-side textured $(3.3 \Omega \cdot \mathrm{cm}, 180 \mu \mathrm{m}$ thickness) and double-side chemically polished $(3.7 \Omega \cdot \mathrm{cm}, 180 \mu \mathrm{m}$ thickness) n-type Cz-Si wafers were used to measure $\rho_{\mathrm{c}}$ and $J_{0, \text { metal }}$ to assess the contact performance. After wafer cleaning using $\mathrm{O}_{3} / \mathrm{HCl} /$ $\mathrm{DI} \mathrm{H}_{2} \mathrm{O}$ and $\mathrm{HF} / \mathrm{HCl}$ solutions, an $8 \mathrm{~nm}$ thick intrinsic a-Si:H layer was deposited on the front and rear of the substrates by plasmaenhanced chemical vapor deposition (PECVD). After a short HF dip, a $\mathrm{TiO}_{x}$ layer was deposited using a spatial thermal atomic layer deposition (ALD) tool on the front and rear side of the substrates to make a symmetrical sample structure while varying the film thickness from 1 to $4 \mathrm{~nm}$. Either TDMAT $\left(0.43 \AA /\right.$ cycle at $\left.225{ }^{\circ} \mathrm{C}\right)$ or TTIP $\left(0.18 \AA /\right.$ cycle at $\left.200^{\circ} \mathrm{C}\right)$ was used as the Ti precursor and $\mathrm{H}_{2} \mathrm{O}$ as the oxidant species.

For the $J_{0, \text { metal }}$ characterization, a very thin $\mathrm{Yb}(4 \mathrm{~nm}) / \mathrm{Ag}(5 \mathrm{~nm})$ stack was sequentially thermally evaporated on top of the i-a-Si:H/ $\mathrm{TiO}_{x}$ layers at the rear side without breaking the vacuum (see Figure $1 \mathrm{a}, \mathrm{b})$. The $J_{0}$ value was determined using quasi-steady-state (a)

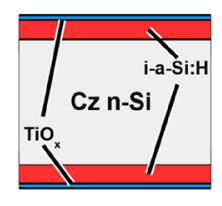

(b)

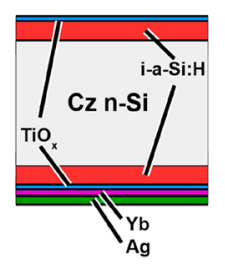

(c)

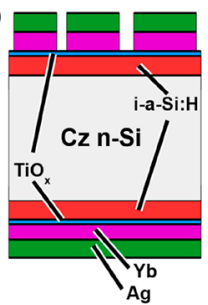

Figure 1. Schematic sample structure to determine: (a) $J_{0}$, (b) $J_{0 \text { metal }}$ and $(\mathrm{c}) \rho_{\mathrm{c}}$.

photoconductance (QSSPC) measurements. The $J_{0, \text { total }}$ was calculated assuming a typical $J_{\mathrm{SC}}$ value of $36 \mathrm{~mA} / \mathrm{cm}^{2}$ in our SHJ cells. The values of $J_{0, \text { total }}$ for all the samples before and after metallization were compared. The $J_{0, \text { bulk }}$ of the $\mathrm{Cz}$ wafer was determined to be approximately $3 \mathrm{fA} / \mathrm{cm}^{2}$, by comparing the $J_{0, \text { total }}$ of a symmetrical ia-Si:H-passivated $\mathrm{Cz}$ wafer with that of a high-quality float zone wafer (n-type, $200 \mu \mathrm{m}, 3.3 \Omega \cdot \mathrm{cm}$ ).

For $\rho_{\mathrm{c}}$ characterization, an $\mathrm{Yb}(40 \mathrm{~nm}) / \mathrm{Ag}(150 \mathrm{~nm})$ stack was sequentially thermally evaporated on the front side with a shadow mask with a contact pattern and on the rear side without any mask. 
(a)

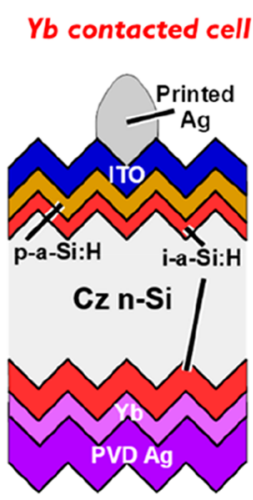

(b)

(c)

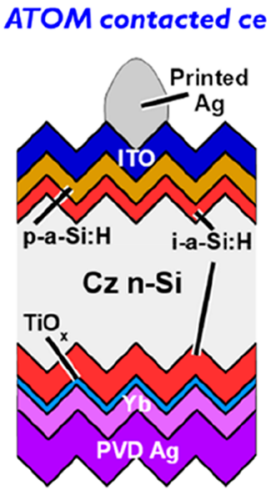

(d)
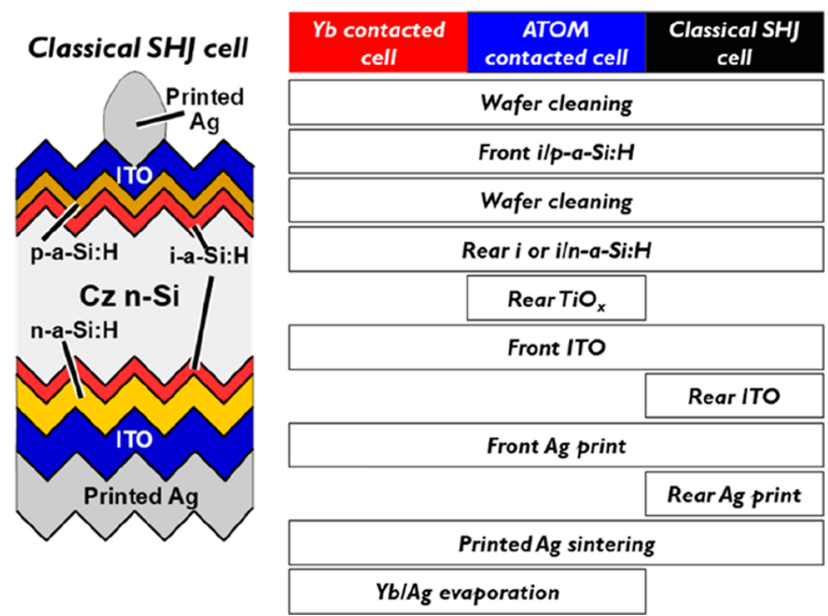

Figure 2. $(\mathrm{a}-\mathrm{c})$ Schematic cross-sectional solar cell structures with the following electron-selective contact structures: $(\mathrm{a}) \mathrm{i}-\mathrm{a}-\mathrm{Si}: \mathrm{H} / \mathrm{Yb} / \mathrm{Ag}(\mathrm{Yb}-$ contacted cell), (b) $\mathrm{i}-\mathrm{a}-\mathrm{Si}: \mathrm{H} / \mathrm{TiO}_{x} / \mathrm{Yb} / \mathrm{Ag}$ (ATOM-contacted cell), and (c) $\mathrm{i} / \mathrm{n}-\mathrm{a}-\mathrm{Si}: \mathrm{H} / \mathrm{ITO} / \mathrm{Ag}$ (classical SHJ cell). (d) Process flowchart for the cell fabrication.
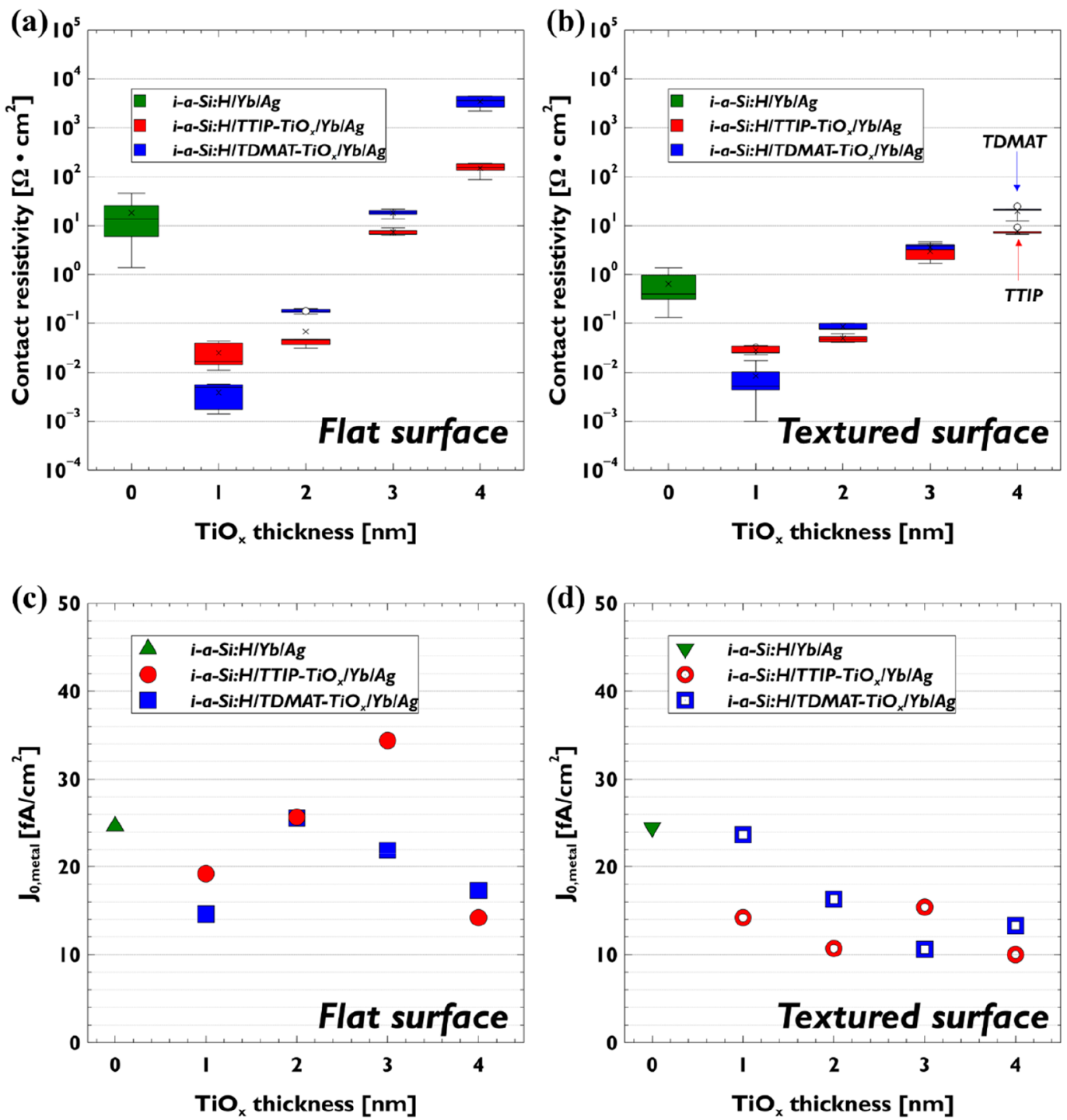

Figure 3. Comparison of the ATOM contact performance as a function of TTIP- and TDMAT-TiO $x$ thickness in terms of $\rho_{\mathrm{c}}$ on flat (a) and on textured (b) surfaces and $J_{0 \text {,metal }}$ on flat (c) and on textured (d) surfaces. 
(see Figure 1c), resulting in contact pads with varying diameters $(250-2000 \mu \mathrm{m})$ on the front side. The $\rho_{\mathrm{c}}$ value of the electron contact was determined using the two-contact-two-terminal method in order to include all resistive components of the contact in the measured $\rho_{c}{ }^{6,34}$ More details on the sample preparation and the methods used to measure and calculate the $\rho_{\mathrm{c}}$ and $J_{0}$ are described in the Supporting Information (Figure S1 and eqs S1-S4) and elsewhere. ${ }^{6,17}$

The layers of this ATOM contact and their interfaces, as well as the elemental distribution, were analyzed by transmission electron microscopy (TEM), high-angle annular dark-field imaging in scanning transmission electron microscopy (HAADF-STEM), and energydispersive X-ray spectroscopy (EDX). The procedure for TEM sample preparation is explained in the Supporting Information.

2.1.2. Solar Cells. The ATOM contact structure was applied in two-side-contacted SHJ cells. The schematic structures of the three cell types fabricated in this work are shown in Figure $2 a-c$. All of the cell structures investigated had the same hole-selective contact featuring the $\mathrm{i} / \mathrm{p}-\mathrm{a}-\mathrm{Si}: \mathrm{H} / \mathrm{ITO} / \mathrm{Ag}$ stack on the front side. On the rear side different electron-selective contacts were applied: $\mathrm{i}-\mathrm{a}-\mathrm{Si}: \mathrm{H} /$ $\mathrm{Yb} / \mathrm{Ag}$ ( $\mathrm{Yb}$-contacted cell) and $\mathrm{i}-\mathrm{a}-\mathrm{Si}: \mathrm{H} / \mathrm{TDMAT}-\mathrm{TiO}_{x} / \mathrm{Yb} / \mathrm{Ag}$ (ATOM-contacted cell) as dopant-free electron-selective contact candidates, and the reference electron-selective contact, $\mathrm{i} / \mathrm{n}$-a-Si:H/ ITO/Ag, which is commonly used in a classical SHJ cell. These contact structures will be simply referred to as $\mathrm{Yb}$-contacted, ATOMcontacted, and classical SHJ cell, respectively.

To fabricate these solar cells as summarized in Figure $2 \mathrm{~d}$ and also described in ref 17 , n-type $\mathrm{Cz}-\mathrm{Si}$ wafers $(4.8 \Omega \cdot \mathrm{cm}, 180 \mu \mathrm{m}$ thickness) with double-side textured surfaces were used. After HF:HCl: $\mathrm{O}_{3}$ and $\mathrm{HF}: \mathrm{HCl}$ cleaning, ${ }^{35}$ the $8 \mathrm{~nm}$ thick i-a-Si:H and 8 $\mathrm{nm}$ thick $\mathrm{p}-\mathrm{a}-\mathrm{Si}: \mathrm{H}$ layers were deposited on the textured front side. Subsequently, after a short HF cleaning, i-a-Si:H and n-a-Si:H layers with thicknesses of 4 and $8 \mathrm{~nm}$, respectively, were deposited at $175^{\circ} \mathrm{C}$ by PECVD for the classical SHJ sample, while only an i-a-Si:H layer with a thickness of $8 \mathrm{~nm}$ was deposited on the other samples. The reason for the different $\mathrm{i}-\mathrm{a}-\mathrm{Si}: \mathrm{H}$ thickness is that, for the classical SHJ cell, a $4 \mathrm{~nm}$ thick $\mathrm{i}$-a-Si:H layer is sufficient to achieve the best cell results. On the other hand, for cells incorporating an ATOM contact, an $8 \mathrm{~nm}$ thick $\mathrm{i}$-a-Si:H layer is needed ${ }^{6}$ to achieve high-quality passivation in the absence of $\mathrm{n}-\mathrm{a}-\mathrm{Si}: \mathrm{H}$. The rear side of the three cell types were prepared differently. For the ATOM-contacted cell, after a short HF dip, a $1 \mathrm{~nm}$ thick TDMAT-based $\mathrm{TiO}_{x}$ layer was deposited by ALD. ITO on the front side was deposited by sputtering for the three cell types, while ITO on the rear side was deposited only for the classical SHJ cells. Subsequently, a Ag front grid (with fingers $80 \mu \mathrm{m}$ wide and $17 \mu \mathrm{m}$ high) was realized for all of the cells using screenprinting, and full-area $\mathrm{Ag}$ (17 $\mu \mathrm{m}$ thick) at the rear side of the classical SHJ cells was also performed by screen-printing. All the cells were then annealed using a belt furnace at $160^{\circ} \mathrm{C}$ for about $25 \mathrm{~min}$ in $\mathrm{N}_{2}$ atmosphere to sinter the printed $\mathrm{Ag}$ contacts. For the $\mathrm{Yb}$-contacted and ATOM-contacted cells, a $40 \mathrm{~nm}$ thick $\mathrm{Yb}$ and a $150 \mathrm{~nm}$ thick $\mathrm{Ag}$ stack was thermally evaporated (sequentially without vacuum break) on the rear side of the cells. As the final step, the wafers were diced into solar cells of $5 \times 5 \mathrm{~cm}^{2}$ with an active cell area of $4 \times 4 \mathrm{~cm}^{2}$.

The illuminated IV parameters were measured with an aperture opening of the same size as the active cell area of $4 \times 4 \mathrm{~cm}^{2}$ under calibrated illumination (AM $1.5 \mathrm{G}, 1000 \mathrm{~W} / \mathrm{m}^{2}$ at $25^{\circ} \mathrm{C}$ ). External quantum efficiency (EQE) and reflectance were measured using an illumination spot size of $1.5 \times 1.5 \mathrm{~cm}^{2}$. Therefore, the EQE and reflectance results include the shading and reflection effects of the front metal grid.

2.2. Annealing Experiments. 2.2.1. Test Structures. To investigate the thermal stability of the contact structures investigated in this work, another set of samples, with the structure given in Figure 1c, was prepared for contact resistivity measurements using textured wafers, with and without the $\mathrm{TiO}_{x}$ layer, in a manner similar to that described in section 2.1. These samples were annealed at 150 or 180 ${ }^{\circ} \mathrm{C}$ in $\mathrm{N}_{2}$ atmosphere using a rapid thermal annealing system. After every $10 \mathrm{~min}$ of annealing, the $\rho_{\mathrm{c}}$ was measured. These particular annealing temperatures were chosen because the temperature range of $150-180^{\circ} \mathrm{C}$ is used during the sintering of printed $\mathrm{Ag}$ for $\mathrm{SHJ}$ solar cells and during the lamination process for module fabrication.

2.2.2. Solar Cells. After cell fabrication, the ATOM-contacted solar cell was annealed in a rapid thermal annealing system to evaluate its thermal stability, using a method described elsewhere. ${ }^{3}$ The illuminated IV characteristics were measured after successive anneals in $\mathrm{N}_{2}$ atmosphere for $10 \mathrm{~min}$ each, and at incrementally increasing temperatures between 150 and $225^{\circ} \mathrm{C}$ with a temperature step of 25 ${ }^{\circ} \mathrm{C}$. Therefore, the last measured point corresponds to a cumulative annealing time of $40 \mathrm{~min}$.

\section{RESULTS AND DISCUSSION}

3.1. Contact Performance Evaluation. To get a better understanding of the ATOM contact, the performance parameters of this contact, such as $\rho_{\mathrm{c}}$ and $J_{0 \text {,metal }}$, were investigated as a function of (1) $\mathrm{Ti}$ precursor for $\mathrm{TiO}_{x}$ growth, (2) $\mathrm{TiO}_{x}$ thickness, and (3) topography of the c-Si substrate.

As shown in Figure $3 \mathrm{a}, \mathrm{b}$, when the $\mathrm{Yb} / \mathrm{Ag}$ metal stack is in direct contact with $\mathrm{i}-\mathrm{a}-\mathrm{Si}: \mathrm{H}$ in the absence of $\mathrm{TiO}_{x}$, the $\rho_{\mathrm{c}}$ value is very high on both flat and textured surfaces likely due to the formation of a Schottky energy barrier as a result of metal Fermi level pinning. The corresponding $\rho_{c}$ values are all above $0.1 \Omega \cdot \mathrm{cm}^{2}$, which is typically considered as the upper limit for the integration of any contact into silicon solar cells. ${ }^{5,36}$ For the ATOM contact, the $\mathrm{TiO}_{x}$ thickness has a strong impact on $\rho_{\mathrm{c}}$. The $\rho_{\mathrm{c}}$ values in a MIS (metal-insulator-semiconductor) contact depend strongly on the thickness of the insulator, ${ }^{37}$ which is $\mathrm{TiO}_{x}$ in this study and which is positioned between the $\mathrm{i}-\mathrm{a}-\mathrm{Si}: \mathrm{H}$ and the $\mathrm{Yb}$ layers. An ohmic contact is achieved when the TTIP-TiO thickness is 1 or $2 \mathrm{~nm}$ and when the $\mathrm{TDMAT}^{-\mathrm{TiO}_{x}}$ thickness is $1 \mathrm{~nm}$ in the ATOM-contact structure. All the other contacts are Schottky contacts. An overview of the IV curves and the method used to determine $\rho_{c}$ of the Schottky contacts in this study is described in the Supporting Information. Note that the five $\rho_{\mathrm{c}}$ values of each condition are included in the box graphs of Figure $3 \mathrm{a}, \mathrm{b}$. The optimum thickness of the $\mathrm{TiO}_{x}$ layer is the one for which the $E_{\mathrm{F} \text {,metal }}$ pinning is effectively reduced while the tunneling resistance through the layer is still as low as possible. This explains why the lowest $\rho_{\mathrm{c}}$ was achieved for a $\mathrm{TiO}_{x}$ thickness of $1 \mathrm{~nm}$ for both $\mathrm{Ti}$ precursor cases: for TDMAT-TiO ${ }_{x}$, this corresponds to $1.7 \mathrm{~m} \Omega \cdot \mathrm{cm}^{2}$ on a flat surface and $1.0 \mathrm{~m} \Omega \cdot \mathrm{cm}^{2}$ on a textured surface, while for TTIP-TiO $x$, this is $11 \mathrm{~m} \Omega \cdot \mathrm{cm}^{2}$ on a flat surface and $23 \mathrm{~m} \Omega \cdot \mathrm{cm}^{2}$ on a textured surface. Whereas TDMAT-TiO ${ }_{x}$ exhibits lower $\rho_{\mathrm{c}}$ at $1 \mathrm{~nm}$ thickness compared to TTIP-TiO $x$, the opposite is true for higher $\mathrm{TiO}_{x}$ thicknesses. This faster increase in $\rho_{c}$ for TDMAT-TiO $\mathrm{T}_{x}$ is typically resulting from different tunneling resistance of the layer ${ }^{38}$ which might be induced by slight variations in thickness (i.e., slightly thicker TDMAT-TiO ${ }_{x}$ ) or/and by differences in density of oxygen vacancies in $\mathrm{TiO}_{\mathrm{x}}$, which affects electron density and band bending. ${ }^{39}$

Furthermore, the $\rho_{\mathrm{c}}$ values of $\mathrm{i}-\mathrm{a}-\mathrm{Si}: \mathrm{H} / \mathbf{2}$ nm-TTIP-TiO ${ }_{x} /$ $\underline{\mathrm{Ca}} / \mathrm{Al}$ (on a flat surface) ${ }^{17}$ and $\mathrm{i}-\mathrm{a}-\mathrm{Si}: \mathrm{H} / \mathbf{2} \mathbf{~ n m - T T I P - T i O}{ }_{x} /$ $\underline{\mathrm{Yb}} / \mathrm{Ag}$ (this work, on a flat surface) are in the similar range of several tens of $\mathrm{m} \Omega \cdot \mathrm{cm}^{2}$. This means that the difference of $0.3-$ $0.4 \mathrm{eV}$ in work function between $\mathrm{Ca}(\Phi=2.9 \mathrm{eV})$ and $\mathrm{Yb}(\Phi$ $=2.5-2.6 \mathrm{eV})$ might not significantly affect the $\rho_{\mathcal{c}}$, or that this difference might have been screened out due to the nonoptimal $\mathrm{TiO}_{x}$ thickness of $2 \mathrm{~nm}$ in the MIS contact. ${ }^{40}$

As to the $J_{0, \text { metal }}$ of the ATOM contacts, the flat and textured surfaces are comparable for each $\mathrm{TiO}_{x}$ thickness, and a weak decreasing trend is observed with respect to the $\mathrm{TiO}_{x}$ thickness (see Figure $3 \mathrm{c}, \mathrm{d}$ ). However, since there is no direct contact 
(a)

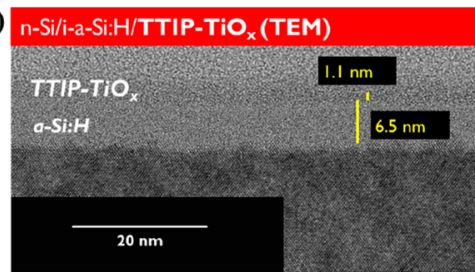

(c) n-Sili-a-Si:H/TTIP-TiO $\mathbf{x}$ (EDX)

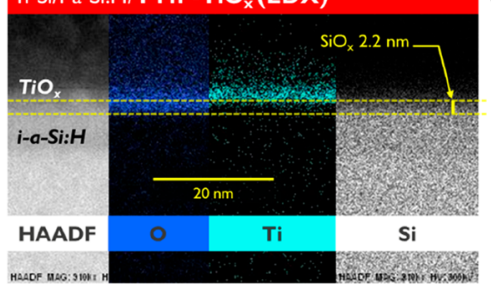

(b) n-Sili-a-Si:H/TDMAT-TiO $\times$ (TEM)

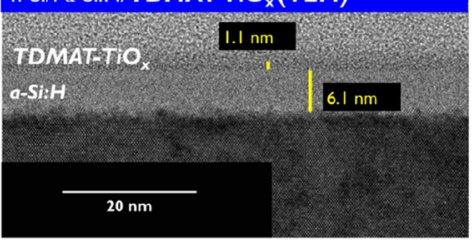

(d) n-Si/i-a-Si:H/TDMAT-TiO ${ }_{x}($ EDX)

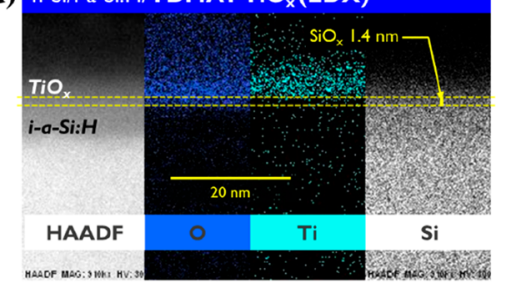

Figure 4. TEM cross-sectional images for ATOM contact structures ( $a, b)$ and chemical component distribution images measured by EDX

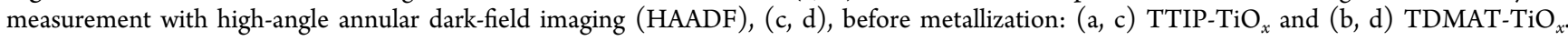

(a)

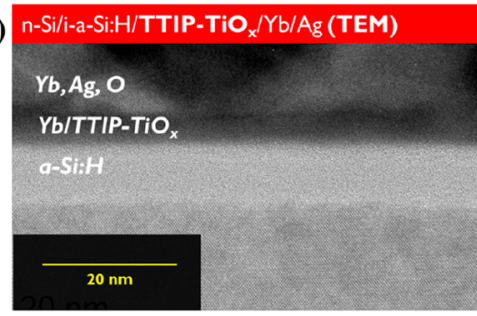

(c)

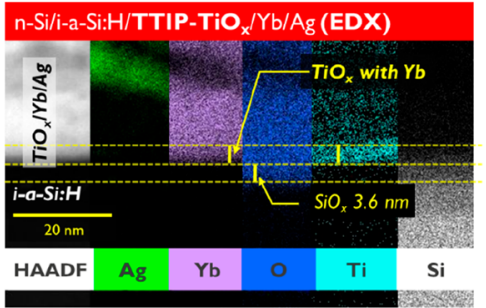

(b) n-Sili-a-Si:H/TDMAT-TiO ${ }_{x} / Y b / A g(T E M)$

$\mathrm{Yb}, \mathrm{Ag}, \mathrm{O}$

YGITDMAT-TIO

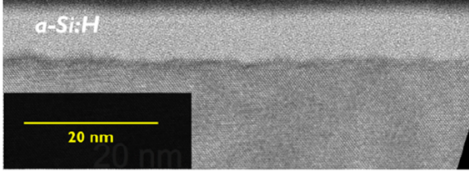

(d) n-Si/i-a-Si:H/TDMAT-TiO ${ }_{x} /$ Yb/Ag (EDX)

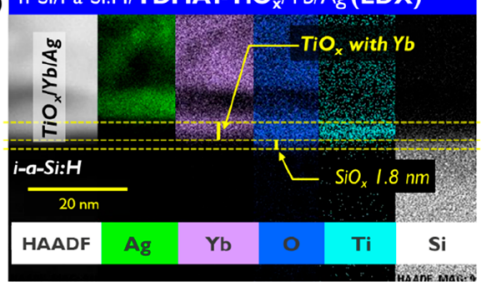

Figure 5. TEM cross-sectional image of ATOM contact structures ( $a, b)$ and chemical component distribution images measured by EDX measurement (c, d) after metallization of $\mathrm{Yb} / \mathrm{Ag}:(\mathrm{a}, \mathrm{c}) \mathrm{TTIP}^{\mathrm{TiO}}{ }_{x}$ and $(\mathrm{b}, \mathrm{d}) \mathrm{TDMAT}^{\mathrm{T}} \mathrm{TiO}_{x}$.

between the absorber and the $\mathrm{TiO}_{x}$ layer, it is not very surprising that the $J_{0, \text { metal }}$ does not strongly depend on the $\mathrm{TiO}_{x}$ thickness, as the passivation quality is largely determined by the $\mathrm{i}-\mathrm{a}-\mathrm{Si}: \mathrm{H}$ layer. Taken together, a $\mathrm{TiO}_{x}$ thickness of $1 \mathrm{~nm}$ with both $\mathrm{Ti}$ precursors appears to be the optimal condition for solar cells because of the resulting lowest $\rho_{\mathrm{c}}$ on textured surfaces (see Figure $3 \mathrm{~b}$ ) in combination with a low $J_{0 \text {,metal }}$ below $25 \mathrm{fA} / \mathrm{cm}^{2}$ (see Figure 3d).

To investigate the contact structure in more detail, a TEM analysis was carried out on a textured sample with $1 \mathrm{~nm} \mathrm{TiO}_{x}$ before and after metallization (see Figures 4 and 5). As can be seen in Figure 4a,b, epitaxially grown crystallized a-Si:H at the $\mathrm{c}-\mathrm{Si} / \mathrm{a}-\mathrm{Si} \mathrm{H}$ interface is shown because of a phase transition from crystalline to amorphous, which has been reported elsewhere. ${ }^{41,42}$ This phenomenon could be mitigated by applying a porous a-Si:H layer on $\mathrm{c}-\mathrm{Si}{ }^{43,44}$ As for the $\mathrm{TiO}_{x}$ the thickness of the deposited $\mathrm{TiO}_{x}$ layer corresponds to the nominal thickness of $1 \mathrm{~nm}$, and the $\mathrm{TiO}_{x}$ layer is closed while it conformally covers the $\mathrm{i}-\mathrm{a}-\mathrm{Si}: \mathrm{H}$ surface. As shown in Figure $4 \mathrm{c}$,d, the interfacial $\mathrm{SiO}_{x}$, formed as a result of the ALD $\mathrm{TiO}_{x}$ process, can be found underneath both TTIP- and TDMAT$\mathrm{TiO}_{x}$, although the thickness of this $\mathrm{SiO}_{x}$ layer is slightly different in both cases. The $\mathrm{SiO}_{x}$ thickness increases after metal evaporation as shown in Figure 5, but the thickness increase is more pronounced for TTIP-TiO ${ }_{x}$. Such interfacial $\mathrm{SiO}_{x}$ formation has already been shown in the literature ${ }^{17}$ and it is probably the result of oxygen migration from the $\mathrm{TiO}_{x}$ toward the substrate during the $\mathrm{TiO}_{x}$ deposition, ${ }^{45}$ as there was no additional thermal treatment. The thicker $\mathrm{SiO}_{x}$ layer formed underneath the TTIP- $\mathrm{TiO}_{x}$ layer might be due to the longer processing time that is needed for TTIP-TiO ${ }_{x}$ when compared to the $\mathrm{TDMAT}^{-} \mathrm{TiO}_{x}$ process. Also, a different oxygen concentration of the $\mathrm{TiO}_{x}$ layers might contribute to the effect. Nevertheless, a relatively lower $\rho_{\text {c }}$ value of the contact stack with $1 \mathrm{~nm}$ of TDMAT-TiO ${ }_{x}$ compared to that with $1 \mathrm{~nm}$ of TTIP-TiO ${ }_{x}$ is probably due not only to the slightly thinner ia-Si:H layer but also to the significantly thinner $\mathrm{SiO}_{x}$ layer when compared to TTIP-TiO .

Even without an additional postdeposition thermal annealing treatment, the $\mathrm{Yb}$ layer is partially mixed with $\mathrm{Ag}$. According to the literature, ${ }^{46}$ temperatures above $446{ }^{\circ} \mathrm{C}$ are required to form an $\mathrm{Yb}-\mathrm{Ag}$ alloy. Nevertheless, the driving force to alloy both metals may be different when combining very thin layers of $\mathrm{Yb}$ and $\mathrm{Ag}$ and may be influenced by the presence of any other impurities in the contact stack. This mixing might result in the negligible difference observed above 
(a)

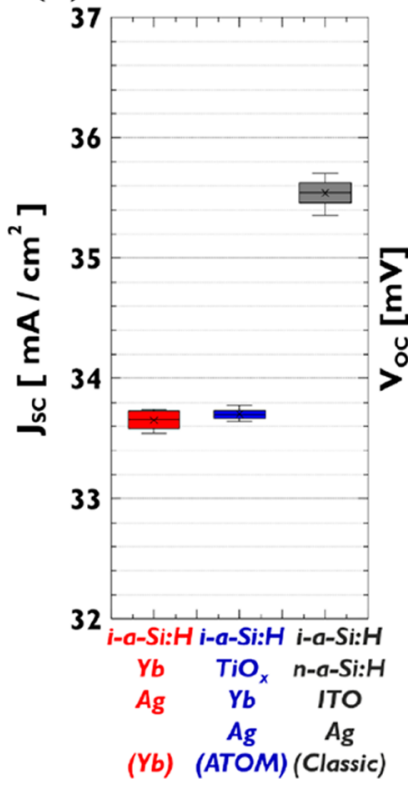

(b)

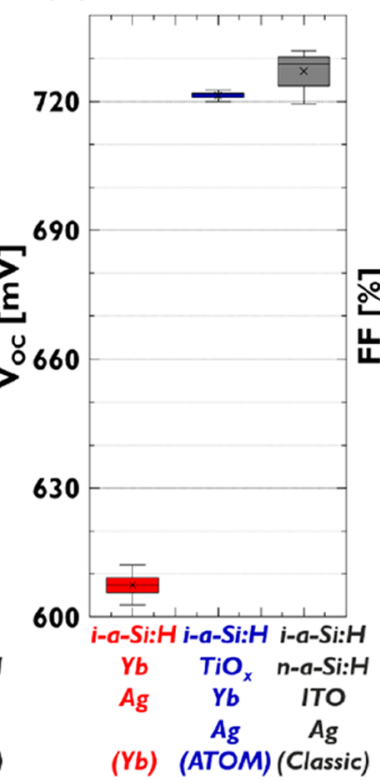

(c)

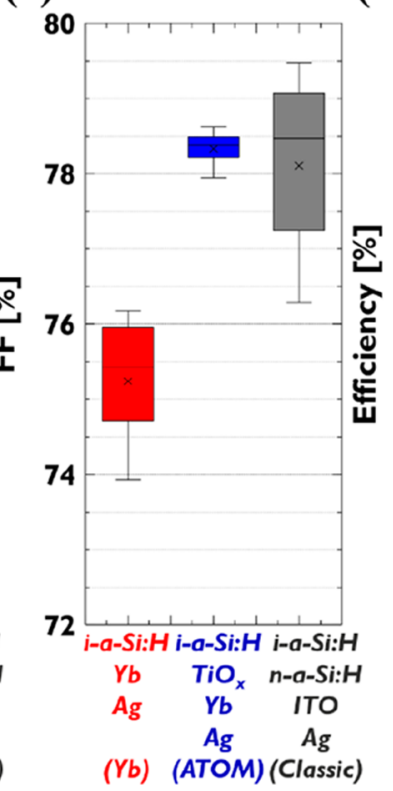

(d)

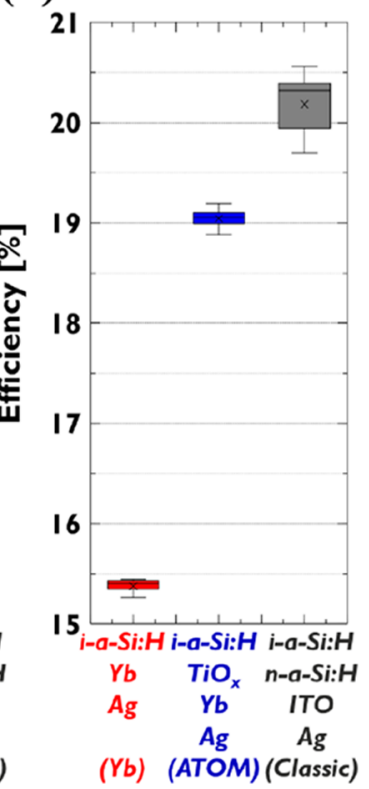

Figure 6. Light IV results of the solar cells with different electron contacts: (a) $J_{\mathrm{SC}}$, (b) $V_{\mathrm{OC}}$, (c) FF, and (d) efficiency. The numbers of samples are 4,4 , and 8 for $\mathrm{Yb}$-contacted, ATOM-contacted, and classical SHJ cells, respectively.

Table 1. Champion Solar Cells for Each of the Different Rear Contact Structures (Cell Area, $16 \mathrm{~cm}^{2}$ )

\begin{tabular}{lcccccc}
\multicolumn{1}{c}{ structure } & rear surface & $J_{\mathrm{SC}}\left(\mathrm{mA} / \mathrm{cm}^{2}\right)$ & $V_{\mathrm{OC}}(\mathrm{mV})$ & $\mathrm{FF}(\%)$ & $\eta(\%)$ & $R_{\mathrm{S}}\left(\Omega \cdot \mathrm{cm}^{2}\right)$ \\
$\mathrm{i}-\mathrm{a}-\mathrm{Si}: \mathrm{H} / \mathrm{Yb} / \mathrm{Ag}$ & textured & 33.5 & 607 & 75.9 & 15.4 & 1.8 \\
$\mathrm{i}-\mathrm{a}-\mathrm{Si}: \mathrm{H} / \mathrm{TDMAT}-\mathrm{TiO} \mathrm{N}_{x} / \mathrm{Yb} / \mathrm{Ag}(\mathrm{ATOM})$ & textured & 33.8 & 723 & 78.6 & 19.2 & 0.97 \\
$\mathrm{i} / \mathrm{n}-\mathrm{a}-\mathrm{Si}: \mathrm{H} / \mathrm{ITO} / \mathrm{Ag}$ & textured & 35.4 & 732 & 79.5 & 20.6 & 1.1 \\
\hline
\end{tabular}

between $\mathrm{Yb}$ and $\mathrm{Ca}$ as the low work function metal in terms of $\rho_{\mathrm{c}}$.

Moreover, both TTIP- and TDMAT-TiO $x$ layers have been in-diffused with $\mathrm{Yb}$, which might make for more favorable condition for downward band bending. When $\mathrm{Yb}$ acts as a dopant in $\mathrm{TiO}_{x}$, the Fermi level of $\mathrm{TiO}_{x}$ could be shifted up because $\mathrm{Yb}$ reduces the density of deep traps in the $\mathrm{TiO}_{x}$ layer. ${ }^{47} \mathrm{Yb}$ nevertheless forms a closed layer on top of the $\mathrm{TiO}_{x}$ layer (see Figure $5 c, d$ ), such that the low work function of $\mathrm{Yb}$ can still induce downward band bending in the contact region. According to the literature, a few angstroms of metal is already sufficient to bring metal-induced band bending to the underlayer, ${ }^{48}$ and even when part of the $\mathrm{Yb}$ layer oxidizes to $\mathrm{YbO}_{x}$, the low work function associated with the desired downward band bending is preserved. ${ }^{49}$ Although the metal layers were mixed during the process, $\mathrm{Yb}$ and $\mathrm{Ag}$ do not pass through the $\mathrm{TiO}_{x}$ layer and thus there is no diffusion of metal into the $\mathrm{i}-\mathrm{a}-\mathrm{Si}: \mathrm{H}$, which would have led to a dramatic increase in $J_{0} . \mathrm{Yb}$ confinement by $\mathrm{TiO}_{x}$ will be discussed further in the section on thermal stability of the ATOM contacts.

3.2. Integration of ATOM Contacts into SHJ Solar Cells. Since the lowest $\rho_{c}$ value is obtained for a $1 \mathrm{~nm}$ thick TDMAT-TiO ${ }_{x}$ layer, with a corresponding $J_{0 \text {,metal }}$ of $24 \mathrm{fA} / \mathrm{cm}^{2}$ on a textured surface (see Figure $3 \mathrm{~b}, \mathrm{~d}$ ), TDMAT-TiO $x$ with a thickness of $1 \mathrm{~nm}$ in combination with $\mathrm{Yb}$ was tested further in solar cells. The schematic cell structures with the different candidates for the electron-selective contacts are shown in Figure 2.

The illuminated IV parameters for the three cell types are shown in Figure 6, and the parameters of the champion cell of each group are listed in Table 1 . The $\mathrm{Yb}$-contacted (no $\mathrm{TiO}_{x}$ and no n-a-Si:H) solar cells perform the worst, particularly in terms of $V_{\mathrm{OC}}$ and FF. As reported in the literature, ${ }^{17,36,50}$ the high $\rho_{\mathrm{c}}$ values obtained for this contact structure due to the existence of a Schottky barrier result not only in a FF loss but also in a $V_{\mathrm{OC}}$ loss. For the case of $\mathrm{Al}^{51,52}$ or $\mathrm{Ni}^{53}$ on a-Si:H, metal-induced crystallization of a-Si:H led to severe passivation degradation resulting in a low $V_{\mathrm{OC}}$. However, $\mathrm{Yb}$ seems not to crystallize $\mathrm{i}-\mathrm{a}-\mathrm{Si}: \mathrm{H}$, as indicated by the low $J_{0 \text {,metal }}$ value of 25 $\mathrm{fA} / \mathrm{cm}^{2}$ which is similar to the ATOM contact which contained noncrystallized a-Si:H (see Figure $3 \mathrm{c}$,d). The $\mathrm{TiO}_{x}$ layer in the ATOM contact significantly increases the FF and the $V_{\mathrm{OC}}$ of the solar cells with respect to $\mathrm{Yb}$-contacted solar cells. This also correlates well with the much lower $\rho_{\mathrm{c}}$ value for this contact, which is the result of the expected metal Fermi depinning effect of the $\mathrm{TiO}_{x}$ layer. As such, the FF and the $V_{\mathrm{OC}}$ of the ATOM-contacted cells are at a level similar to those of the classical SHJ cells, which suggests that a strong band bending could be achieved by $\mathrm{Yb}$ in combination with a $1 \mathrm{~nm}$ thick $\mathrm{TiO}_{x}$ layer, even without the use of any doped layers (e.g., n-a-Si:H).

Both the $\mathrm{Yb}$-contacted and the ATOM-contacted solar cells showed a lower average $J_{\mathrm{SC}}$ compared to the classical $\mathrm{SHJ}$ devices. In a previous study, an i-a-Si:H/TTIP-TiO ${ }_{x} / \mathrm{Ca} / \mathrm{Al}$ contact structure was applied to achieve a solar cell efficiency of $18.2 \%$ with a $V_{\mathrm{OC}}$ of $711 \mathrm{mV}$ and $\mathrm{FF}$ of $72.9 \%$. In comparison, the champion ATOM-contacted cell in this work yielded a higher $V_{\mathrm{OC}}$ of $723 \mathrm{mV}$ and a higher $\mathrm{FF}$ of $78.6 \%$ resulting in an efficiency of $19.2 \%$ (see Table 1 ). 
(a)

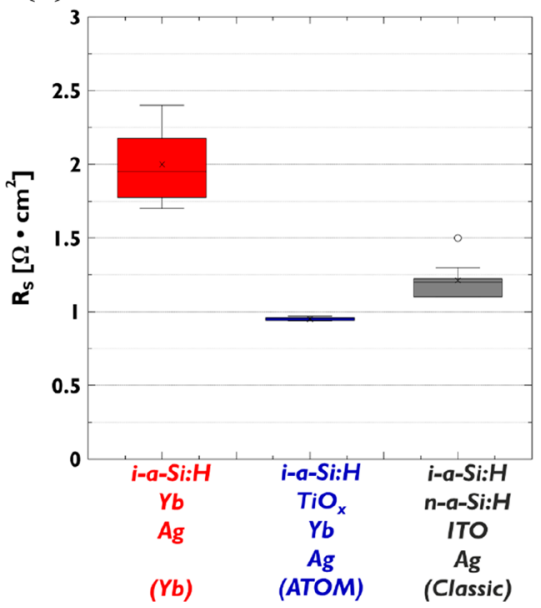

(b)

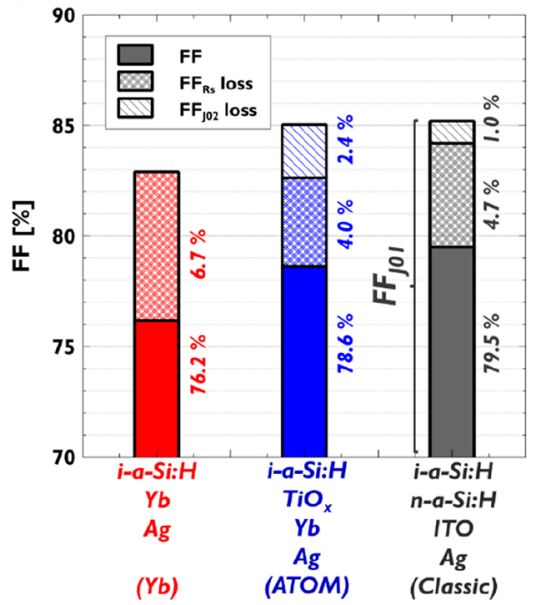

Figure 7. (a) Series resistance of the solar cells in this work implementing different electron contacts. (b) Fill factor loss analysis of the champion cells in each group.

(a)
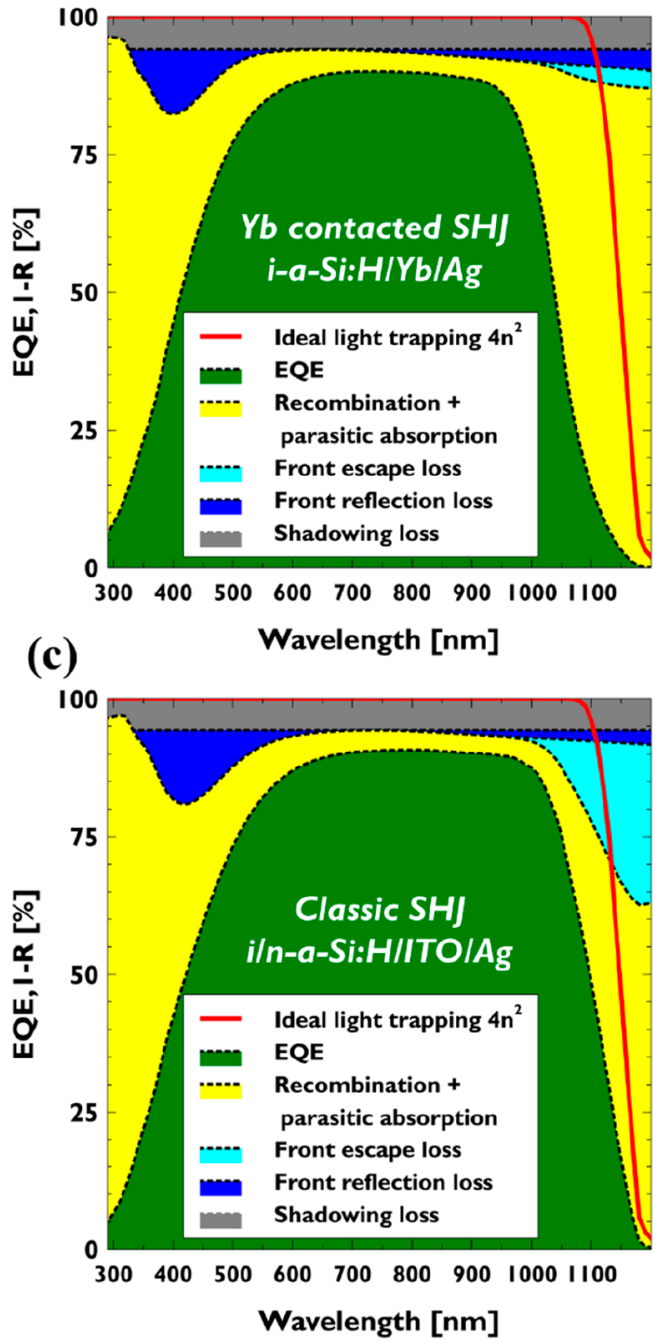

(b)

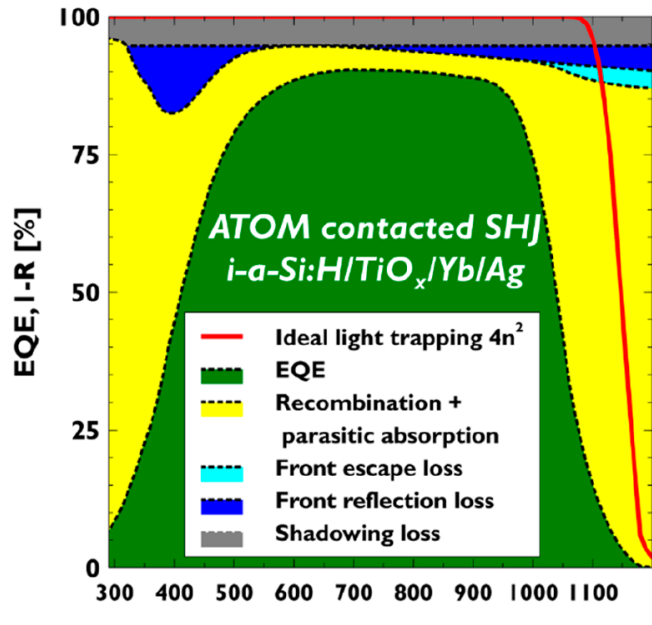

(d)

Wavelength [nm]

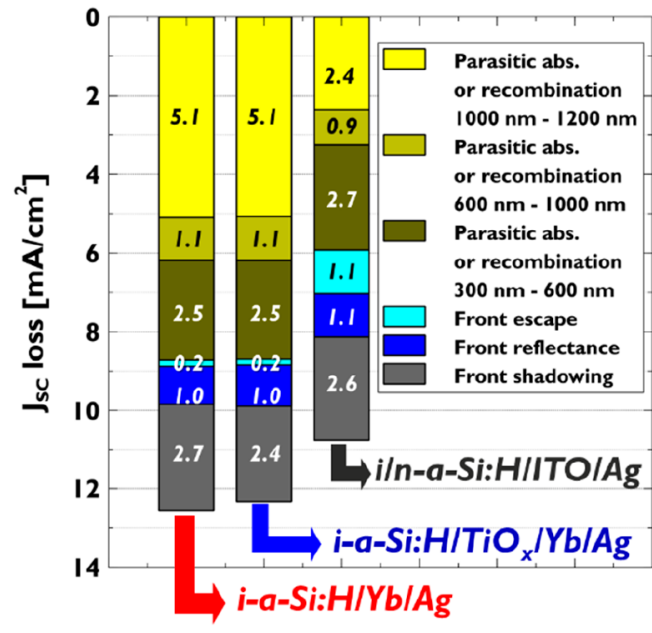

Figure 8. Results of the optical loss analysis for the champion solar cell of each group: (a) $\mathrm{i}-\mathrm{a}-\mathrm{Si}: \mathrm{H} / \mathrm{Yb} / \mathrm{Ag}$ contact, $(\mathrm{b}) \mathrm{i}-\mathrm{a}-\mathrm{Si} ; \mathrm{H} / \mathrm{TiO}{ }_{x} / \mathrm{Yb} / \mathrm{Ag}$ contact, and (c) i/n-a-Si:H/ITO/Ag contact. (d) Comparison of the absolute $J_{\mathrm{SC}}$ loss associated with each loss component in the solar cells.

A detailed FF loss analysis was done on the cells of this work presented in Table 1 . The $R_{\mathrm{S}}$ value for the solar cells in this work is quantified by using the Bowden method ${ }^{54}$ and is plotted in Figure 7a, while the FF loss analysis is carried out 
Table 2. Benchmarking Results of SHJ Solar Cells Using i-a-Si:H/TiO ${ }_{x}$ Stack in Electron Contacts

\begin{tabular}{|c|c|c|c|c|c|c|c|}
\hline electron contact structure & $\mathrm{TiO}_{x}$ thickness $(\mathrm{nm})$ & metal work function $(\mathrm{eV})$ & $J_{\mathrm{SC}}\left(\mathrm{mA} / \mathrm{cm}^{2}\right)$ & $V_{\mathrm{OC}}(\mathrm{mV})$ & FF (\%) & $\eta(\%)$ & size $\left(\mathrm{cm}^{2}\right)$ \\
\hline $\mathrm{i}-\mathrm{a}-\mathrm{Si}: \mathrm{H} / \mathrm{TiO}_{x} / \mathrm{Al}^{61}$ & 3.5 & 4.3 & & 677 & 54.0 & & 4 or 1 \\
\hline i-a-Si:H/ $\mathrm{TiO}_{x} / \mathrm{ITO} / \mathrm{Ag}^{61}$ & 3.5 & $4.4-4.5$ & & 492 & 29.2 & & 4 or 1 \\
\hline $\mathrm{i}-\mathrm{a}-\mathrm{Si}: \mathrm{H} / \mathrm{TiO}_{x} / \mathrm{Al} / \mathrm{ITO} / \mathrm{Ag}^{62}$ & & 4.3 & 35.5 & 612 & 71.3 & 15.5 & 4 \\
\hline $\mathrm{i}$-a-Si:H$/ \mathrm{TiO}_{x} / \mathrm{Ca} / \mathrm{Al}^{17}(\mathrm{ATOM})$ & 2 & 2.9 & 35.1 & 711 & 72.9 & 18.2 & 16 \\
\hline $\mathrm{i}-\mathrm{a}-\mathrm{Si}: \mathrm{H} / \mathrm{TiO}_{x} / \mathrm{LiF} / \mathrm{Al}^{3}$ & 1.5 & 2.9 & 37.5 & 713 & 78.1 & 20.9 & 4 \\
\hline $\mathrm{i}-\mathrm{a}-\mathrm{Si}: \mathrm{H} / \mathrm{TiO}_{x} / \underline{\mathrm{Yb}} / \mathrm{Ag}$ (ATOM, this work) & 1 & $2.5-2.6$ & 33.8 & $\underline{723}$ & $\underline{78.6}$ & 19.2 & $\underline{16}$ \\
\hline
\end{tabular}

following the approach of Khanna et al. $^{55}$ and is plotted in Figure $7 \mathrm{~b}$. The FF loss related to the shunt resistance is not mentioned due to its negligible contribution. Moreover, for the $\mathrm{i}-\mathrm{a}-\mathrm{Si}: \mathrm{H} / \mathrm{Yb} / \mathrm{Ag}$-contacted solar cells, the sum of $\mathrm{FF}$ and $\mathrm{FF}_{R_{s}}$ already exceeds $\mathrm{FF}_{J_{01}}$, which is the maximum available $\mathrm{FF}$ considering only $J_{01}$ recombination and therefore $\mathrm{FF}_{J_{02}}$ is not depicted. When $R_{\mathrm{S}}$ of cells is too high, such as in the case of the $\mathrm{Yb}$-contacted cell, the accuracy of the loss analysis is reduced and some mismatch in values of loss factors could occur. ${ }^{17}$ As shown in Figure $7 \mathrm{a}$ and Table 1, the $R_{\mathrm{S}}$ value of the $\mathrm{Yb}$-contacted cells is significantly higher than that of the ATOM-contacted cells. The contribution of the thin Ag and $\mathrm{Yb}$ layers to the $R_{\mathrm{S}}$ of the solar cells is likely marginal due to the very low sheet resistance of the metal stack of about 0.15 $\Omega / \square$ when considering $\rho_{\mathrm{Ag}}$ and $\rho_{\mathrm{Yb}}$ values of $2.3 \mu \Omega \cdot \mathrm{cm}^{56,57}$ and $45 \mu \Omega \cdot \mathrm{cm}^{58}$ respectively. In addition, a full-area metal chuck in the illuminated IV measurements could further reduce the resistance loss resulting from $R_{\text {sheet }}$ of the metal at the rear side of the cells. This is reflected in the fact that the main FF loss component for $\mathrm{Yb}$-contacted cells, in Figure $7 \mathrm{~b}$, is the series resistance, $\mathrm{FF}_{R_{\mathrm{s}}}$. Inserting a $1 \mathrm{~nm}$ thick $\mathrm{TiO}_{x}$ layer between $\mathrm{i}-\mathrm{a}-\mathrm{Si}: \mathrm{H}$ and $\mathrm{Yb}$ significantly reduces the $\mathrm{FF}_{R_{\mathrm{s}}}$ loss from $6.7 \%_{\text {abs }}$ to $4 \%_{\text {abs }}$, which corresponds to a $40 \%_{\text {rel }}$ reduction due to the presence of $\mathrm{TiO}_{x}$ that likely induces $E_{\mathrm{F} \text {,metal }}$ depinning. In fact, the $\mathrm{FF}_{R_{\mathrm{s}}}$ loss of the ATOM-contacted cell is even lower than that for the classical SHJ cells and the ATOM contact enables a lower contact resistivity of only a few $\mathrm{m} \Omega \cdot \mathrm{cm}^{2}$ (see Figure 3) compared to $100-200 \mathrm{~m} \Omega \cdot \mathrm{cm}^{2}$ that is known for the traditional i/n-a-Si:H/ITO/Ag contacts. The higher $\mathrm{FF}_{J_{02}}$ loss in the ATOM-contacted solar cells could be attributed to the thicker i-a-Si:H layer and weaker band bending at the electron contact compared to the classical $\mathrm{SHJ}$ contact. This challenge should be adequately addressed to close the gap in performance between the ATOM-contacted and the classical SHJ solar cells.

To understand the optical losses, a detailed $J_{\mathrm{SC}}$ loss analysis was done following the method described in ref 59, which is based on EQE and wavelength-dependent reflectance. In this study, light transmission through the cells was assumed to be zero because of the full-area metallization on the rear side of the cells.

Panels a-c of Figure 8 depict the different spectral losses leading to the eventual EQE, namely, (1) front shading, (2) front reflection, (3) front escape, and (4) parasitic and/or recombination losses (at three wavelength ranges), in the three solar cell types investigated in this work. These losses are quantified in terms of their noncontribution to the $J_{\mathrm{SC}}$ of the cell in Figure 8d. The losses associated with the front shading and the front reflection are approximately the same for all of the devices because those contributions are defined by the front side structure (metal grid, textured surface, and so on), which is common to all devices investigated here. The front escape refers to the reflected light at the rear side, especially middle and long wavelength light, which can escape back out of the front side without being fully absorbed by the silicon. The parasitic absorption losses come from optically unwanted absorption in a-Si:H, ITO, $\mathrm{TiO}_{x}$ and/or metal layers, which eventually do not contribute to the device current. The recombination losses are due to an imperfect collection of generated carriers. A solid red line in the figures denotes the ideal EQE for a cell where the c-Si wafer thickness is $180 \mu \mathrm{m}$.

In all three cell structures, there is a similar significant amount of parasitic absorption on the front side of the solar cell due to the presence of ITO and i/p-a-Si:H layers. However, at long wavelengths (1000-1200 nm), the parasitic absorption/recombination losses are different for the three contact structures, which is the reason for the lower $J_{\mathrm{SC}}$ in the ATOM- or Yb-contacted solar cells compared to the reference $\mathrm{SHJ}$ devices. Low EQE at long wavelength might occur because of the close proximity of the metal to the c-Si absorber on the rear side, leading to the penetration of the evanescent waves to the rear metal and surface plasmons at the metal reflector. $^{60}$ These parasitic losses are prevented in the SHJ cells by having an ITO layer which acts as an optical buffer. Those parasitic absorption losses could be reduced by applying a highly reflective metal, such as $\mathrm{Al}$ or Ag. However, those metals yield a high contact resistivity due to insufficiently low work functions and other side effects (e.g., p-doping effect of Al). As discussed in the Introduction, $\mathrm{Al}$ can be used when it is combined with alkaline rare-earth metal fluoride $\mathrm{LiF}$ or $\mathrm{MgF}$, which do have a low work function of $2.9 \mathrm{eV}^{4}$ and $3.5 \mathrm{eV}^{16}$, respectively. For these cases, precise thickness control for layers thinner than $1 \mathrm{~nm}$ has to be carefully considered. Therefore, highly reflective low work function metals would be very interesting for solar cell application.

As shown in Table 2, when an electron contact was formed using thick $\mathrm{TiO}_{x}$ with relatively high work function metals, simultaneously achieving FF above $70 \%$ with $V_{\mathrm{OC}}$ above 700 $\mathrm{mV}$ is very challenging. However, $\mathrm{i}-\mathrm{a}-\mathrm{Si}: \mathrm{H}$ and $\mathrm{a} \mathrm{TiO}_{x}$ layer thinner than $2 \mathrm{~nm}$, combined with a low work function metal, was very effective in attaining high $V_{\mathrm{OC}}$ and FF. The ATOMcontacted cell of this work achieved superior $V_{\mathrm{OC}}$ and FF in relatively larger cells thanks to the a-Si:H passivation, the likely Fermi level depinning effect induced by the $\mathrm{TiO}_{x}$ layer, and the low work function metal, $\mathrm{Yb}$.

\section{THERMAL STABILITY OF THE ATOM CONTACTS}

4.1. Influence of Annealing on $\rho_{c}$. A good reliability of the metal contacts in a solar cell is obviously an essential criterion. Furthermore, the layers that are present in a solar cell need to be able to withstand the lamination process that is required to fabricate modules. Therefore, an additional thermal budget has to be applied after the cell manufacturing process. Recently, Bullock et al. have demonstrated acceptable thermal 

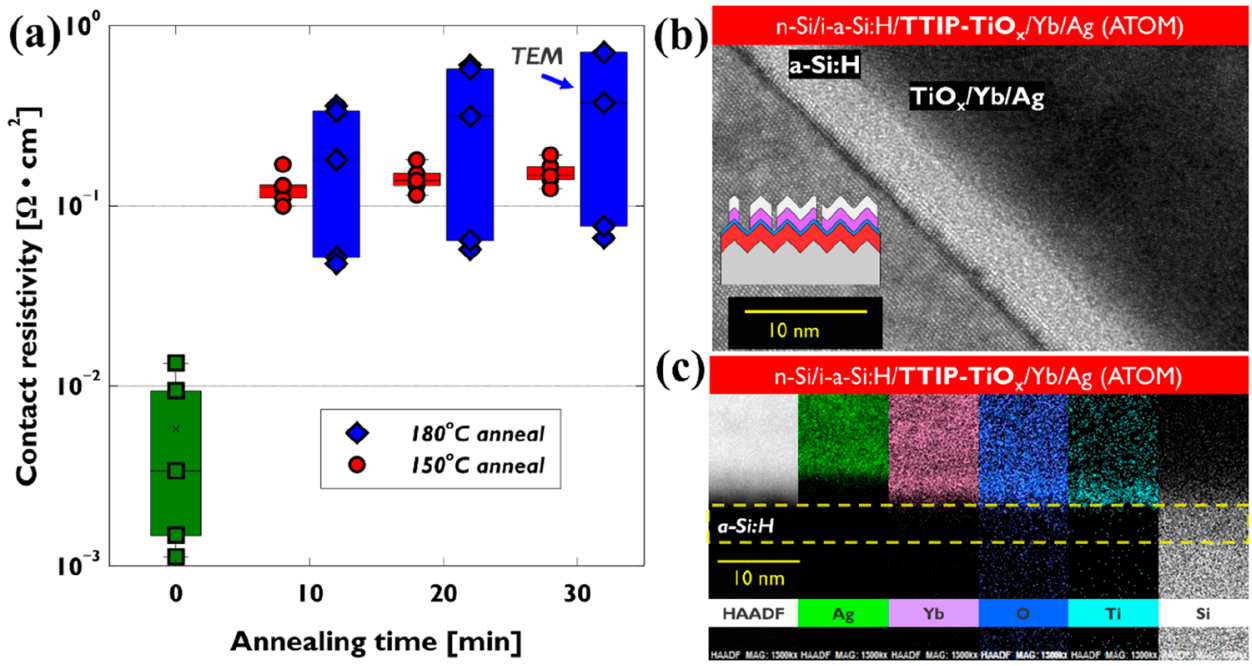

Figure 9. (a) Contact resistivity dependence on annealing temperature and time (five data points per group). (b) TEM cross-sectional images for ATOM contact and (c) chemical component distribution images measured by EDX, after annealing at $180{ }^{\circ} \mathrm{C}$ for $30 \mathrm{~min}$.

stability in solar cells that included a $\mathrm{TiO}_{x}$ layer between a-Si:H and $\mathrm{LiF} / \mathrm{Al}$, which passed the damp-heat test $\left(1000 \mathrm{~h}, 85^{\circ} \mathrm{C}\right.$, $85 \%$ humidity). ${ }^{3}$

To evaluate the thermal stability, postannealing treatments were done on the ATOM-contact structure at two different temperatures and the $\rho_{\mathrm{c}}$ was intermittently measured. Figure 9, which plots $\rho_{\mathrm{c}}$ as a function of cumulative annealing time, shows that as the annealing time increases, the $\rho_{\mathrm{c}}$ value of the ATOM contact increases. At a higher annealing temperature, the escalation in $\rho_{\mathrm{c}}$ is faster. After annealing at $150{ }^{\circ} \mathrm{C}$ for 30 min, the average $\rho_{\text {c }}$ of the ATOM contact is $0.15 \Omega \cdot \mathrm{cm}^{2}$, which is slightly above the earlier mentioned limit of $0.1 \Omega \cdot \mathrm{cm}^{2}$ for device integration. The annealing-induced change in $\rho_{\mathrm{c}}$ could be linked to the transformation of the interface at the contact region. To investigate this, TEM and EDX analyses were conducted using the samples annealed at $180{ }^{\circ} \mathrm{C}$ for $30 \mathrm{~min}$. As shown in Figure 9b, the $\mathrm{i}-\mathrm{a}-\mathrm{Si}: \mathrm{H}$ passivation layer is clearly distinguished from the blurred $\mathrm{TiO}_{x} / \mathrm{Yb} / \mathrm{Ag}$ stack. Moreover, no $\mathrm{Yb}$ is found in the $\mathrm{i}-\mathrm{a}-\mathrm{Si}: \mathrm{H}$ layer of the ATOM contact (see Figure 9c). $\mathrm{TiO}_{x}$ seems to work as a barrier layer against $\mathrm{Yb}$ diffusion; therefore, the presence of the $\mathrm{TiO}_{x}$ layer may be beneficial to preserve the passivation quality even after the annealing process. The increase in $\rho_{\mathrm{c}}$ after annealing for the ATOM contacts (see Figure 9a) might be related to oxygen diffusion from the $\mathrm{TiO}_{x}$ layer into the metal stack of $\mathrm{Yb} / \mathrm{Ag}$ such as that observed in the cases of $\mathrm{TiO}_{x} / \mathrm{Ti}^{63}$ and $\mathrm{TiO}_{x} / \mathrm{Ca} /$ Al. ${ }^{19}$ This could be inferred from the EDX map shown in Figure $9 c$, where $\mathrm{O}$ is detected throughout the thickness between and including the $\mathrm{TiO}_{x}$ and $\mathrm{Yb}$ layers. The oxygen movement from $\mathrm{TiO}_{x}$ to the metal might be preferred due to the already existing $\mathrm{SiO}_{x}$ layer between $\mathrm{TiO}_{x}$ and $\mathrm{i}-\mathrm{a}-\mathrm{Si}: \mathrm{H}$ (Figure $4 \mathrm{c}$ and Figure 5c). Similar to the results of $\mathrm{Yu}$ et al., ${ }^{63}$ as fabricated, the ATOM contact is a metal-insulatorsemiconductor contact on $\mathrm{i}-\mathrm{a}-\mathrm{Si}: \mathrm{H}$. However, as the total thermal budget on the contact is increased, the ATOM contact structure seems to gradually change from a MIS contact to a semi-MS (metal-semiconductor) contact by losing oxygen in the $\mathrm{TiO}_{x}$ layer, ${ }^{63}$ which may finally become a semi-metallic TiO. ${ }^{64}$ Accordingly, the $E_{\mathrm{F}, \text { metal }}$ depinning properties of the asfabricated ATOM contact may progressively disappear, which may lead to an increase in $\rho_{\mathrm{c}}$. The large scatter on the $\rho_{\mathrm{c}}$ value for the sample annealed at $180{ }^{\circ} \mathrm{C}$ is not very clear (see Figure $9 \mathrm{a})$. It might come from nonuniformity of the sample. Some interaction between a-Si:H and metal might have occurred through pinholes or cracks formed in the metal layer once exceeding a certain annealing temperature. Nonetheless, an increasing trend in $\rho_{\mathrm{c}}$ is seen after annealing at higher temperature. In addition, studies on annealing times below 10 min could be very interesting because there is a big jump in the result after annealing for $10 \mathrm{~min}$.

4.2. Solar Cells. In order to quantify the impact of the annealing on the IV parameters of the solar cells fabricated in this work, the cells were successively annealed for $10 \mathrm{~min}$ at incrementally increasing temperatures. Figure 10 shows the IV results for the cells after those successive anneals.

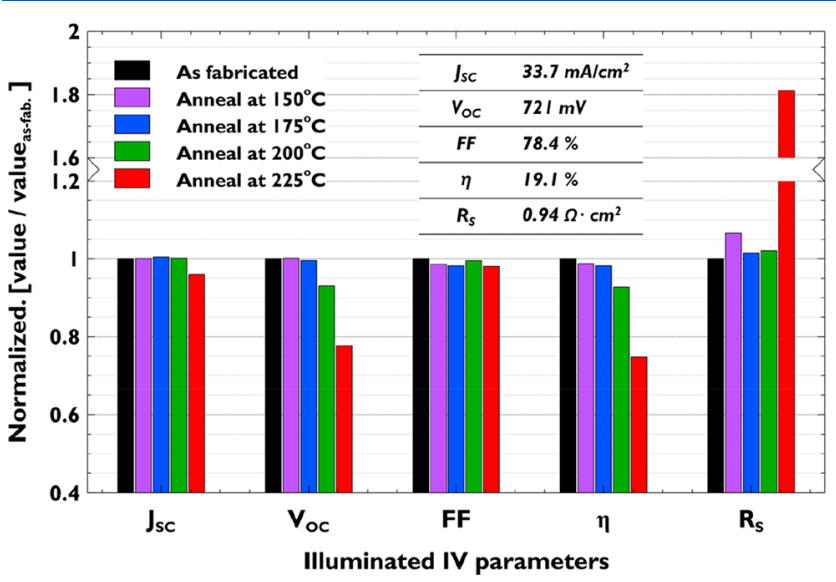

Figure 10. Normalized IV results after successive annealing for 10 min at each temperature between 150 and $225{ }^{\circ} \mathrm{C}$. Initial cell parameters before annealing are written in the figure. The Bowden method $^{54}$ was used for $R_{S}$ characterization.

$J_{S C}$ and FF were maintained in successive cumulative anneals until an annealing temperature of $225{ }^{\circ} \mathrm{C}$; however, the $V_{\mathrm{OC}}$ value starts to significantly decrease from the annealing at 200 ${ }^{\circ} \mathrm{C}$ onward, which also results in a reduction in the efficiency. As the annealing temperature increases, the cell efficiency gradually decreases from the initial efficiency of $19.1 \%$ for as- 
fabricated solar cells, to $18.8 \%$ and $18.7 \%$ after consecutively annealing at 150 and $175{ }^{\circ} \mathrm{C}$, respectively, which means that 98.2\% of the initial efficiency is preserved at this point. Although the $\rho_{\mathrm{c}}$ value of the ATOM contact structure probably already increases by about a factor of 10 after annealing at 150 ${ }^{\circ} \mathrm{C}$ for $10 \mathrm{~min}$ (see Figure 9a), a rise in the $\rho_{\mathrm{c}}$ of the ATOM contact structure only marginally contributes to the total $R_{\mathrm{S}}$ until the annealing at $200{ }^{\circ} \mathrm{C}$. The earlier mentioned limit of $0.1 \Omega \cdot \mathrm{cm}^{2}$ in $\rho_{\mathrm{c}}$ for the solar cells might be too stringent or the separately extracted $\rho_{\mathrm{c}}$ could be higher than the actual values in the complete solar cell. After annealing at $225{ }^{\circ} \mathrm{C}$, the $R_{\mathrm{S}}$ of the cell increases significantly and a dominant reduction in the efficiency is due to the reduction in $V_{\mathrm{OC}}$ of the cell. It is believed that modified interface properties reduce the downward band bending and passivation quality at the contact region.

These annealing test results imply that a temperature below $175{ }^{\circ} \mathrm{C}$ is preferred for the subsequent processes of the ATOM-contacted cells to maintain the cell performance. Fortunately, the ATOM contact structure is compatible with module encapsulation process temperatures of around 150 ${ }^{\circ} \mathrm{C}$. ${ }^{65}$ Furthermore, an increased $\rho_{\mathrm{c}}$ after annealing at $175{ }^{\circ} \mathrm{C}$ does not induce a detrimental effect on the FF or the efficiency of the ATOM-contacted solar cells.

In addition, increasing the thermal stability further is one of the important topics for further research to ensure the stability of these solar cells. Preserving the MIS contact structure of the ATOM contact through interfacial engineering could be one of the pathways for improving thermal stability of these solar cells. On the other hand, a stability test at module level after encapsulation, i.e., damp-heat test or thermal cycling test, could also be very interesting to understand the current state for long-term stability.

\section{CONCLUSION}

An electron-selective contact, termed ATOM contact, is fabricated using an $\mathrm{i}-\mathrm{a}-\mathrm{Si}: \mathrm{H} / \mathrm{TiO}_{x} / \mathrm{Yb}$ contact structure with $\mathrm{Ag}$ as the capping metal layer. The contact performance is investigated in terms of $\rho_{\mathrm{c}}$ and $J_{0, \text { metal }}$. It appears that both $\mathrm{Ti}$ precursors used in this work for $\mathrm{TiO}_{x}$ deposition, TTIP and TDMAT, show comparable contact characteristics. In addition, the surface topography of the c-Si substrate, flat or textured, did not influence the contact properties. Concerning the $\mathrm{TiO}_{x}$ layer thickness in the $\mathrm{i}-\mathrm{a}-\mathrm{Si}: \mathrm{H} / \mathrm{TiO}_{x} / \mathrm{Yb} / \mathrm{Ag}$ (ATOM) contact, $1 \mathrm{~nm}$ seems optimal to achieve depinning of $E_{\mathrm{F} \text { metal }}$ in a MIS contact configuration. ATOM contacts with $\mathrm{Yb}$ as a low work function metal have been successfully integrated into $\mathrm{SHJ}$ cells, enabling a champion cell efficiency of $19.2 \%$ with a $V_{\text {OC }}$ of 723 $\mathrm{mV}$.

The annealing temperature and time strongly affect the $\rho_{\mathcal{O}}$ so the thermal stability of the contact has to be carefully considered. It was found that when annealing the ATOM contact at temperatures not exceeding $175^{\circ} \mathrm{C}$, it is possible to preserve $98.2 \%$ of the initial efficiency thanks to the barrier function of the $\mathrm{TiO}_{x}$ layer in this contact, which blocks metal diffusion.

This study could be a stepping stone for achieving highly efficient and more reliable solar cells without the need for doping processes or doped layers.

\section{ASSOCIATED CONTENT}

\section{Supporting Information}

The Supporting Information is available free of charge on the ACS Publications website at DOI: 10.1021/acsaem.8b01969.

Contact resistivity characterization method and TEM sample preparation method (PDF)

\section{AUTHOR INFORMATION}

\section{Corresponding Author}

*E-mail: Jinyoun.cho@imec.be.

ORCID $\odot$

Jinyoun Cho: 0000-0002-3524-1256

W. M. M. Kessels: 0000-0002-7630-8226

Notes

The authors declare no competing financial interest.

\section{ACKNOWLEDGMENTS}

We gratefully acknowledge the financial support of imec's industrial affiliation program for Si PV. The work of J.M. was supported by The Netherlands Organisation for Scientific Research under the Dutch TTW-VENI Grant 15896. imec is a partner in EnergyVille (www.energyville.be), a collaboration between the Flemish research partners KU Leuven, VITO, imec, and UHasselt in the field of sustainable energy and intelligent energy systems.

\section{REFERENCES}

(1) Adachi, D.; Hernández, J. L.; Yamamoto, K. Impact of Carrier Recombination on Fill Factor for Large Area Heterojunction Crystalline Silicon Solar Cell with 25.1\% Efficiency. Appl. Phys. Lett. 2015, 107, 233506.

(2) Holman, Z. C.; Descoeudres, A.; Barraud, L.; Fernandez, F. Z.; Seif, J. P.; De Wolf, S.; Ballif, C. Current Losses at the Front of Silicon Heterojunction Solar Cells. IEEE J. Photovoltaics 2012, 2, 7-15.

(3) Bullock, J.; Wan, Y.; Xu, Z.; Essig, S.; Hettick, M.; Wang, H.; Ji, W.; Boccard, M.; Cuevas, A.; Ballif, C.; et al. Stable Dopant-Free Asymmetric Heterocontact Silicon Solar Cells with Efficiencies above 20\%. ACS Energy Lett. 2018, 3, 508-513.

(4) Bullock, J.; Hettick, M.; Geissbühler, J.; Ong, A. J.; Allen, T.; Sutter-Fella, C. M.; Chen, T.; Ota, H.; Schaler, E. W.; De Wolf, S.; et al. Efficient Silicon Solar Cells with Dopant-Free Asymmetric Heterocontacts. Nat. Energy 2016, 1, 15031.

(5) Melskens, J.; van de Loo, B. W. H.; Macco, B.; Black, L. E.; Smit, S.; Kessels, W. M. M. Passivating Contacts for Crystalline Silicon Solar Cells: From Concepts and Materials to Prospects. IEEE J. Photovoltaics 2018, 8, 373-388.

(6) Cho, J.; Debucquoy, M.; Recaman Payo, M.; Malik, S.; Filipič, M.; Radhakrishnan, H. S.; Bearda, T.; Gordon, I.; Szlufcik, J.; Poortmans, J. Contact Resistivity Reduction on Lowly-Doped n-Type Si Using a Low Work Function Metal and a Thin TiOx Interfacial Layer for Doping-Free Si Solar Cells. Energy Procedia 2017, 124, 842-850 (7th International Conference on Silicon Photovoltaics, Silicon PV 2017) .

(7) Yang, X.; Zheng, P.; Bi, Q.; Weber, K. Silicon Heterojunction Solar Cells with Electron Selective TiOx Contact. Sol. Energy Mater. Sol. Cells 2016, 150, 32-38.

(8) Yang, X.; Bi, Q.; Ali, H.; Davis, K.; Schoenfeld, W. V.; Weber, K. High-Performance $\mathrm{TiO} 2$-Based Electron-Selective Contacts for Crystalline Silicon Solar Cells. Adv. Mater. 2016, 28, 5891.

(9) Yang, X.; Weber, K.; Hameiri, Z.; De Wolf, S. Industrially Feasible, Dopant-Free, Carrier-Selective Contacts for High-Efficiency Silicon Solar Cells. Prog. Photovoltaics 2017, 25, 896-904.

(10) Yu, J.; Fu, Y.; Zhu, L.; Yang, Z.; Yang, X.; Ding, L.; Zeng, Y.; Yan, B.; Tang, J.; Gao, P.; et al. Heterojunction Solar Cells with 
Asymmetrically Carrier-Selective Contact Structure of MolybdenumOxide/Silicon/Magnesium-Oxide. Sol. Energy 2018, 159, 704-709.

(11) Macco, B.; Black, L. E.; Melskens, J.; van de Loo, B. W. H.; Berghuis, W. H.; Verheijen, M. A.; Kessels, W. M. M. Atomic-Layer Deposited $\mathrm{Nb} 2 \mathrm{O} 5$ as Transparent Passivating Electron Contact for c-Si Solar Cells. Sol. Energy Mater. Sol. Cells 2018, 184, 98-104.

(12) Macco, B.; Bivour, M.; Deijkers, J. H.; Basuvalingam, S. B.; Black, L. E.; Melskens, J.; van de Loo, B. W. H.; Berghuis, W. J. H.; Hermle, M.; Kessels, W. M. M. Effective Passivation of Silicon Surfaces by Ultrathin Atomic-Layer Deposited Niobium Oxide. Appl. Phys. Lett. 2018, 112, 242105.

(13) Wan, Y.; Karuturi, S. K.; Samundsett, C.; Bullock, J.; Hettick, M.; Yan, D.; Peng, J.; Narangari, P. R.; Mokkapati, S.; Tan, H. H.; et al. Tantalum Oxide Electron-Selective Heterocontacts for Silicon Photovoltaics and Photoelectrochemical Water Reduction. ACS Energy Lett. 2018, 3, 125-131.

(14) Yang, X.; Aydin, E.; Xu, H.; Kang, J.; Hedhili, M.; Liu, W.; Wan, Y.; Peng, J.; Samundsett, C.; Cuevas, A.; et al. Tantalum Nitride Electron-Selective Contact for Crystalline Silicon Solar Cells. Adv. Energy Mater. 2018, 8, 1800608.

(15) Allen, T. G.; Bullock, J.; Zheng, P.; Vaughan, B.; Barr, M.; Wan, Y.; Samundsett, C.; Walter, D.; Javey, A.; Cuevas, A. Calcium Contacts to N-Type Crystalline Silicon Solar Cells. Prog. Photovoltaics 2017, 25, 636-644.

(16) Wan, Y.; Samundsett, C.; Bullock, J.; Allen, T.; Hettick, M.; Yan, D.; Zheng, P.; Zhang, X.; Cui, J.; McKeon, J.; et al. Magnesium Fluoride Electron-Selective Contacts for Crystalline Silicon Solar Cells. ACS Appl. Mater. Interfaces 2016, 8, 14671-14677.

(17) Cho, J.; Melskens, J.; Debucquoy, M.; Recamán Payo, M.; Jambaldinni, S.; Bearda, T.; Gordon, I.; Szlufcik, J.; Kessels, W. M. M.; Poortmans, J. Passivating Electron-Selective Contacts for Silicon Solar Cells Based on an a-Si:H/TiOx Stack and a Low Work Function Metal. Prog. Photovoltaics 2018, 26, 835-845.

(18) Cho, J.; Debucquoy, M.; Payo, M. R.; Schapmans, E.; Gordon, I.; Szlufcik, J.; Poortmans, J. Evidence of TiOx Reduction at the SiOx/ TiOx Interface of Passivating Electron-Selective Contacts. AIP Conf. Proc. 2018, 1999, 040005 (SiliconPV Conference 2018) .

(19) Allen, T. G.; Bullock, J.; Jeangros, Q.; Samundsett, C.; Wan, Y.; Cui, J.; Hessler-Wyser, A.; De Wolf, S.; Javey, A.; Cuevas, A. A Low Resistance Calcium/Reduced Titania Passivated Contact for High Efficiency Crystalline Silicon Solar Cells. Adv. Energy Mater. 2017, 7, 1602606.

(20) Macco, B.; Vos, M. F. J.; Thissen, N. F. W.; Bol, A. A.; Kessels, W. M. M. Low-Temperature Atomic Layer Deposition of MoOx for Silicon Heterojunction Solar Cells. Phys. Status Solidi RRL 2015, 9, 393-396.

(21) Bivour, M.; Macco, B.; Temmler, J.; Kessels, W. M. M. E.; Hermle, M. Atomic Layer Deposited Molybdenum Oxide for the Hole-Selective Contact of Silicon Solar Cells. Energy Procedia 2016, 92, 443-449 (Proceedings of the 6th International Conference of Crystalline Silicon Photovoltaics (Silicon PV 2016).

(22) Sacchetto, D.; Jeangros, Q.; Christmann, G.; Barraud, L.; Descoeudres, A.; Geissbuhler, J.; Despeisse, M.; Hessler-Wyser, A.; Nicolay, S.; Ballif, C. ITO/MoOx/a-Si:H(i) Hole-Selective Contacts for Silicon Heterojunction Solar Cells: Degradation Mechanisms and Cell Integration. IEEE J. Photovoltaics 2017, 7, 1584-1590.

(23) Mews, M.; Korte, L.; Rech, B. Oxygen Vacancies in Tungsten Oxide and Their Influence on Tungsten Oxide/Silicon Heterojunction Solar Cells. Sol. Energy Mater. Sol. Cells 2016, 158, 77-83.

(24) Bivour, M.; Zähringer, F.; Ndione, P.; Hermle, M. SputterDeposited WOx and MoOx for Hole Selective Contacts. Energy Procedia 2017, 124, 400-405 (7th International Conference on Silicon Photovoltaics, SiliconPV 2017) .

(25) Gerling, L. G.; Mahato, S.; Morales-Vilches, A.; Masmitja, G.; Ortega, P.; Voz, C.; Alcubilla, R.; Puigdollers, J. Transition Metal Oxides as Hole-Selective Contacts in Silicon Heterojunctions Solar Cells. Sol. Energy Mater. Sol. Cells 2016, 145, 109-115.

(26) Masmitjà, G.; Gerling, L. G.; Ortega, P.; Puigdollers, J.; Martín, I.; Voz, C.; Alcubilla, R. V 2 O x -Based Hole-Selective Contacts for c-
Si Interdigitated Back-Contacted Solar Cells. J. Mater. Chem. A 2017, 5, 9182-9189.

(27) Neusel, L.; Bivour, M.; Hermle, M. Selectivity Issues of MoOx Based Hole Contacts. Energy Procedia 2017, 124, 425-434 (7th International Conference on Silicon Photovoltaics, SiliconPV 2017) .

(28) Geissbühler, J.; Werner, J.; Martin De Nicolas, S.; Barraud, L.; Hessler-Wyser, A.; Despeisse, M.; Nicolay, S.; Tomasi, A.; Niesen, B.; De Wolf, S.; et al. 22.5\% Efficient Silicon Heterojunction Solar Cell with Molybdenum Oxide Hole Collector. Appl. Phys. Lett. 2015, 107, 081601.

(29) Wronski, C. R.; Carlson, D. E. Surface States and Barrier Heights of Metal-Amorphous Silicon Schottky Barriers. Solid State Commun. 1977, 23, 421-424.

(30) Bivour, M. Silicon Heterojunction Solar Cells: Analysis and Basic Understanding. Ph.D. Dissertation, Fraunhofer Verlag: Stuttgart, Germany, 2017.

(31) Matsui, T.; Bivour, M.; Ndione, P.; Hettich, P.; Hermle, M. Investigation of Atomic-Layer-Deposited TiOx as Selective Electron and Hole Contacts to Crystalline Silicon. Energy Procedia 2017, 124, 628-634 (7th International Conference on Silicon Photovoltaic, SiliconPV 2017).

(32) Skriver, H. L.; Rosengaard, N. M. Surface Energy and Work Function of Elemental Metals. Phys. Rev. B: Condens. Matter Mater. Phys. 1992, 46, 7157-7168.

(33) Michaelson, H. B. The Work Function of the Elements and Its Periodicity. J. Appl. Phys. 1977, 48, 4729-4733.

(34) Schroder, D. K. Semiconductor Material and Device Characterization, 3rd ed.; John Wiley \& Sons: Hoboken, NJ, USA, 2005; Vol. 44. DOI: $10.1002 / 0471749095$.

(35) Haslinger, M.; Soha, M.; Jambaldinni, S.; Hajjiah, A.; Szlufcik, J.; Poortmans, J.; John, J. Novel Wet Chemical Cleaning Concepts for High Efficiency Silicon Solar Cells. 33rd European Photovoltaic Solar Energy Conference and Exhibition; WIP Renewable Energies: Munich, Germany, 2017; pp 628-630.

(36) Green, M. A.; Blakers, A. W.; Zhao, J.; Milne, A. M.; Wang, A.; Dai, X. Characterization of 23-Percent Efficient Silicon Solar Cells. IEEE Trans. Electron Devices 1990, 37, 331-336.

(37) Agrawal, A.; Lin, J.; Barth, M.; White, R.; Zheng, B.; Chopra, S.; Gupta, S.; Wang, K.; Gelatos, J.; Mohney, S. E.; et al. Fermi Level Depinning and Contact Resistivity Reduction Using a Reduced Titania Interlayer in N-Silicon Metal-Insulator-Semiconductor Ohmic Contacts. Appl. Phys. Lett. 2014, 104, 112101.

(38) Agrawal, A.; Shukla, N.; Ahmed, K.; Datta, S. A Unified Model for Insulator Selection to Form Ultra-Low Resistivity Metal-InsulatorSemiconductor Contacts to $\mathrm{n}-\mathrm{Si}, \mathrm{n}-\mathrm{Ge}$, and $\mathrm{n}-\mathrm{InGaAs}$. Appl. Phys. Lett. 2012, 101, 042108 .

(39) WahlstroM, E.; Vestergaard, E. K.; Schaub, R.; Rønnau, A.; Vestergaard, M.; Lægsgaard, E.; Stensgaard, I.; Besenbacher, F. Electron Transfer-Induced Dynamics of Oxygen Molecules on the TiO2(110) Surface. Science (Washington, DC, U. S.) 2004, 303, 511513.

(40) Agrawal, A.; Lin, J.; Zheng, B.; Sharma, S.; Chopra, S.; Wang, K.; Gelatos, A.; Mohney, S.; Datta, S. Barrier Height Reduction to $0.15 \mathrm{eV}$ and Contact Resistivity Reduction to $9.1 \times 10^{-9} \Omega-\mathrm{cm}^{2}$ Using Ultrathin $\mathrm{TiO}_{2-x}$ Interlayer between Metal and Silicon. 2013 Symposium on VLSI Technology (VLSIT); IEEE, 2013; pp T200T201.

(41) Abdulraheem, Y.; Gordon, I.; Bearda, T.; Meddeb, H.; Poortmans, J. Optical Bandgap of Ultra-Thin Amorphous Silicon Films Deposited on Crystalline Silicon by PECVD. AIP Adv. 2014, 4, 057122 .

(42) Meddeb, H.; Bearda, T.; Abdelraheem, Y.; Ezzaouia, H.; Gordon, I.; Szlufcik, J.; Poortmans, J. Structural, Hydrogen Bonding and in Situ Studies of the Effect of Hydrogen Dilution on the Passivation by Amorphous Silicon of n-Type Crystalline $\left(\begin{array}{lll}1 & 0 & 0\end{array}\right)$ Silicon Surfaces. J. Phys. D: Appl. Phys. 2015, 48, 415301.

(43) Sai, H.; Chen, P.; Hsu, H.; Matsui, T. Impact of Intrinsic Amorphous Silicon Bilayers in Silicon Heterojunction Solar Cells. J. Appl. Phys. 2018, 124, 103102. 
(44) Macco, B.; Melskens, J.; Podraza, N. J.; Arts, K.; Pugh, C.; Thomas, O.; Kessels, W. M. M. Correlating the Silicon Surface Passivation to the Nanostructure of Low-Temperature a-Si:H after Rapid Thermal Annealing. J. Appl. Phys. 2017, 122, 035302.

(45) Kita, K.; Toriumi, A. Origin of Electric Dipoles Formed at High-k/SiO2 Interface. Appl. Phys. Lett. 2009, 94, 132902.

(46) Gschneidner, K. A.; Calderwood, F. W. The Ag-Yb (SilverYtterbium) System. Bull. Alloy Phase Diagrams 1985, 6, 147-149.

(47) Roose, B.; Pathak, S.; Steiner, U. Doping of TiO2 for Sensitized Solar Cells. Chem. Soc. Rev. 2015, 44, 8326-8349.

(48) Street, R. A. Hydrogenated Amorphous Silicon; Cambridge University Press: Cambridge, U.K., 1991. DOI: 10.1017/ CBO9780511525247.

(49) Bertel, E.; Strasser, G.; Netzer, F. P.; Matthew, J. A. D. Surface Oxidation of Ytterbium. Surf. Sci. 1982, 118, 387-400.

(50) Glunz, S. W.; Nekarda, J.; Mäckel, H.; Cuevas, A. Analyzing Back Contacts of Silicon Solar Cells by Suns-Voc-Measurements at High Illumination Densities. Proceedings of the 22nd European Photovoltaic Solar Energy Conference, Sep. 3-7, 2007, Milan, Italy; EU PVSEC, 2007; pp 849-853.

(51) Schaper, M.; Schmidt, J.; Plagwitz, H.; Brendel, R. 20.1\%Efficient Crystalline Silicon Solar Cell With Amorphous Silicon RearSurface Passivation. Prog. Photovoltaics 2005, 13, 381-386.

(52) Plagwitz, H.; Nerding, M.; Ott, N.; Strunk, H. P.; Brendel, R. Low-Temperature Formation of Local Al Contacts to a-Si:HPassivated Si Wafers. Prog. Photovoltaics 2004, 12, 47-54.

(53) Kawazu, Y.; Kudo, H.; Onari, S.; Arai, T. Low-Temperature Crystallization of Hydrogenated Amorphous Silicon Induced by Nickel Silicide Formation. Jpn. J. Appl. Phys. 1990, 29, 2698-2704.

(54) Bowden, S.; Rohatgi, A. Rapid and Accurate Determination of Series Resistance and Fill Factor Losses in Industrial Silicon Solar Cells. 17th European Photovoltaic Solar Energy Conference and Exhibition, Munich, Germany; EU PVSEC, 2001.

(55) Khanna, A.; Mueller, T.; Stangl, R. A.; Hoex, B.; Basu, P. K.; Aberle, A. G. A Fill Factor Loss Analysis Method for Silicon Wafer Solar Cells. IEEE J. Photovoltaics 2013, 3, 1170-1177.

(56) Zhang, W.; Brongersma, S. H.; Richard, O.; Brijs, B.; Palmans, R.; Froyen, L.; Maex, K. Influence of the Electron Mean Free Path on the Resistivity of Thin Metal Films. Microelectron. Eng. 2004, 76, $146-152$.

(57) Kim, H. C.; Alford, T. L.; Allee, D. R. Thickness Dependence on the Thermal Stability of Silver Thin Films. Appl. Phys. Lett. 2002, $81,4287-4289$.

(58) Bist, B. M. S.; Srivastava, O. N. Electrical Resistivity of Ytterbium Thin Films. Thin Solid Films 1973, 18, 71-75.

(59) Paviet-Salomon, B.; Tomasi, A.; Descoeudres, A.; Barraud, L.; Nicolay, S.; Despeisse, M.; Wolf, S. D.; Ballif, C. Back-Contacted Silicon Heterojunction Solar Cells: Optical-Loss Analysis and Mitigation. IEEE J. Photovoltaics 2015, 5, 1293-1303.

(60) Holman, Z. C.; Filipič, M.; Descoeudres, A.; De Wolf, S.; Smole, F.; Topič, M.; Ballif, C. Infrared Light Management in HighEfficiency Silicon Heterojunction and Rear-Passivated Solar Cells. J. Appl. Phys. 2013, 113, 013107.

(61) Boccard, M.; Yang, X.; Weber, K.; Holman, Z. C. Passivation and Carrier Selectivity of $\mathrm{TiO} 2$ Contacts Combined with Different Passivation Layers and Electrodes for Silicon Solar Cells. In 2016 IEEE 43rd Photovoltaic Specialists Conference (PVSC); IEEE, 2016; pp 2403-2407. DOI: 10.1109/PVSC.2016.7750072.

(62) Sacchetto, D.; Jeangros, Q.; Christmann, G.; Barraud, L.; Descoeudres, A.; Geissbuhler, J.; Despeisse, M.; Hessler-Wyser, A.; Nicolay, S.; Ballif, C. MoOx and TiO2 Carrier Selective Contacts for Dopant-Free SHJs. 7th International Conference on Crystalline Silicon Photovoltaics 2017, Freiburg, Germany, Apr. 3-5, 2017.

(63) Yu, H.; Schaekers, M.; Schram, T.; Demuynck, S.; Horiguchi, N.; Barla, K.; Collaert, N.; Thean, A. V.-Y.; De Meyer, K. Thermal Stability Concern of Metal-Insulator-Semiconductor Contact: A Case Study of Ti/TiO 2 /n-Si Contact. IEEE Trans. Electron Devices 2016, 63, 2671-2676.
(64) Valeeva, A. A.; Rempel', A. A.; Gusev, A. I. Electrical Conductivity and Magnetic Susceptibility of Titanium Monoxide. JETP Lett. 2001, 73, 621-625.

(65) Li, H.-Y.; Perret-Aebi, L.-E.; Chapuis, V.; Ballif, C.; Luo, Y. The Effect of Cooling Press on the Encapsulation Properties of Crystalline Photovoltaic Modules: Residual Stress and Adhesion. Prog. Photovoltaics 2015, 23, 160-169. 